\title{
LA REFORMA DE LOS DELITOS DE FINANCIACIÓN ILEGAL DE PARTIDOS POLÍTICOS: UN DEBATE DESENFOCADO ${ }^{1}$
}

\author{
José León Alapont ${ }^{2}$
}

Resumen: la financiación ha sido tradicionalmente uno de los principales focos de delincuencia en el seno de los partidos, yendo asociada en numerosas ocasiones a sonados escándalos de corrupción. En cambio, hubo que esperar a la reforma del Código Penal operada por la LO $1 / 2015$, de 30 de marzo, para que el legislador español creara ex novo los arts. 304 bis y 304 ter (relativos a la financiación ilegal de partidos políticos). No obstante, y a pesar de la corta vida de estos preceptos, pronto se generaría en el poder legislativo el debate acerca de la conveniencia de modificar dichos artículos. De forma que, constituye el objeto principal de este trabajo analizar las recientes propuestas de reforma de los delitos de financiación ilegal planteadas por los distintos

Recibido: mayo 2019. Aceptado: septiembre 2019

1 El presente artículo se enmarca dentro del Proyecto de Investigación "Criminal compliance programs y elaboración de mapas de riesgo. En especial, en delitos de medio ambiente y corrupción", referencia: RTI2018097572-B-100, concedido por el Ministerio de Ciencia, Innovación y Universidades del Gobierno de España.

2 ORCID ID: 0000-0002-0537-6563. Departamento de Derecho Penal. Facultad de Derecho de la Universitat de València, Avda dels Tarongers s/n, 46022 Valencia. E-mail: Jose.Leon@uv.es 
grupos parlamentarios, para contraponerlas con la que a nuestro juicio debiera ser la modificación que algún día debiera emprender el legislador español.

Palabras claves: financiación ilegal, partidos políticos, corrupción, responsabilidad penal, personas jurídicas.

\title{
THE REFORM OF CRIMES OF ILLEGAL FINANCING OF POLITICAL PARTIES: AN UNFOCUSED DEBATE
}

\begin{abstract}
: financing has traditionally been one of the main sources of crime within the parties, often associated with high-profile corruption scandals. Instead, we had to wait for the reform of the Criminal Code operated by LO 1/2015, of March 30, so that the Spanish legislator created ex novo arts. 304 bis and 304 ter (relating to the illegal financing of political parties). Nevertheless, and despite the short life of these precepts, the debate about the advisability of modifying said articles would soon be generated in the legislature. Thus, the main purpose of this paper is to analyze the recent proposals for the reform of illegal financing crimes raised by the different parliamentary groups, in order to counterpose them with what, in our opinion, should be the modification that the Spanish legislator should one day undertake.
\end{abstract}

Keywords: illegal funding, political parties, corruption, criminal liability, legal entities.

\section{Introducción}

Como se ha encargado de remarcar la mayoría de autores $^{3}$, los vínculos de la corrupción política con la financiación ilegal de los partidos son más que evidentes a tenor de los múltiples casos en que éstos se han visto envueltos ${ }^{4}$. La obtención de recursos económicos en un partido político se reduce a una cuestión de pura supervivencia. Convirtiéndose así en el princi-

3 Vid., por todos, QUINTERO OLIVARES, G.: “Artículo 304 bis y artículo 304 ter", en QUINTERO OLIVARES, G. (Dir.): Comentarios al Código Penal Español. Tomo II, Cizur Menor, Thomson Reuters-Aranzadi, 2016, p. 528.

4 Vid. algunos ejemplos en LEÓN ALAPONT, J.: La responsabilidad penal de los partidos políticos, Valencia, Tirant lo Blanch, 2019, pp. 124 y ss. 
pal foco de actividad ilícita de estas organizaciones, puesto que los ingresos que perciben (tanto públicos como privados) se han mostrado insuficientes para hacer frente a todos los gastos que los partidos tienen. En particular, los relativos a las elecciones, pues éstas se erigen como medio para acceder (en primer lugar) al poder, para mantenerlo o incluso acrecentarlo. Y sólo así, de obtener representación institucional, esto es, de "hacerse visibles", puede garantizarse el futuro de la propia formación política. Por otro lado, la fuerte competencia electoral (ocasionada en parte por la volatilidad del electorado y el multipartidismo), la frecuente sucesión de citas electorales, la configuración del propio sistema de partidos, la anémica falta de democracia interna y transparencia de estas organizaciones, unido al poder institucional que estos copan, se erigen en el caldo de cultivo idóneo para propiciar o tolerar este tipo de prácticas.

En este sentido, la reforma del Código Penal operada en España por la Ley Orgánica 1/2015, de 30 de marzo, trajo consigo una importante novedad: incorporaba a nuestro ordenamiento el delito de financiación ilegal de los partidos políticos (art. 304 bis). Y, relacionado con éste, el de pertenencia a una organización destinada a financiar ilegalmente a aquéllos (art. 304 ter). Ahora bien, este valiente gesto del legislador -dado el elevado grado de autoproteccionismo que tradicionalmente venía caracterizando a las organizaciones partidistas ${ }^{5}$ - pronto sería objeto de acertadas críticas, manifestándose al respecto que la inclusión de estos nuevos delitos respondía más bien a un intento por neutralizar las repercusiones mediáticas y sociales de los múltiples casos de corrupción y no tanto a un firme compromiso por acabar con este tipo de prácticas delictivas de los partidos ${ }^{6}$.

5 Vid. más detenidamente, sobre este fenómeno, MAROTO CALATAYUD, M: "Autorregulación y legitimidad corporativa: democracia interna y control social en partidos políticos y empresas", en ARROYO JIMÉNEZ, L y NIETO MARTÍN, A. (Dirs.): Autorregulación y sanciones, Cizur Menor, Thomson Reuters-Aranzadi, 2015, p. 413.

6 Así, por todos, JAVATO MARTÍN, A. M.: "El delito de financiación ilegal de los partidos políticos (arts. 304 bis y 304 ter CP). Aspectos dogmáticos, 
Así, la configuración que se dio a los delitos de financiación ilegal, fruto de una acusada improvisación, pronto truncaría las expectativas generadas en torno a éstos ${ }^{7}$.

De hecho, dos años más tarde, el 7 de abril de 2017, era publicada la Proposición de Ley Orgánica sobre represión penal de la financiación ilegal de los partidos políticos (promovida por el Grupo Parlamentario Mixto en el Congreso de los Diputados a iniciativa de Compromís), la cual tenía por objeto una modificación del art. 304 ter $\mathrm{CP}^{8}$. Posteriormente, el 15 de noviembre de 2018 se publicaban las enmiendas a dicho articulado, en las que otros grupos parlamentarios instaron una reforma no sólo del art. 304 ter CP, sino también del art. 304 bis $\mathrm{CP}^{9}$. Al análisis de estas propuestas dedicaremos el presente trabajo, pues, si bien es cierto que todas ellas caducaron con la expiración de la XII Legislatura (al disolverse las Cortes y convocarse elecciones para el 28 de abril de 2019) las mismas pueden ser retomadas en una próxima legislatura y, en todo caso, deben ser objeto de consideración por nuestra parte dado que son las únicas que se han planteado en sede legislativa hasta el momento.

\section{Los distintos planteamientos}

A continuación, pasaremos a examinar las distintas propuestas presentadas por los respectivos grupos parlamentarios, que se centran básicamente en modificaciones de los vigentes artículos 304 bis CP y 304 ter CP, así como la creación de nuevas

político-criminales y de derecho comparado, Revista Electrónica de Ciencia Penal y Criminología, núm. 19-26, 2017, p. 41.

7 Vid., sobre este particular, LEÓN ALAPONT, J.: "Partidos políticos y responsabilidad penal de las personas jurídicas: consideraciones en torno a su régimen jurídico y los compliances programs", en MATALLÍN EVANGELIO, Á. (Dir.), Compliance y prevención de delitos de corrupción, Valencia, Tirant lo Blanch, 2018, p. 170.

8 BOCG. Congreso de los Diputados, Serie B, Núm. 155-1, 7 de abril de 2017.

9 BOCG. Congreso de los Diputados, Serie B, Núm. 155-4, 15 de noviembre de 2018. 
conductas delictivas fuera de estos dos preceptos. A tales efectos, se irán destacando y comentando críticamente los cambios que se proponen en relación con el tenor literal de los vigentes tipos penales.

\section{En relación con el art. 304 bis CP.}

\section{Actual redacción:}

1. Será castigado con una pena de multa del triplo al quintuplo de su valor, el que reciba donaciones o aportaciones destinadas a un partido político, federación, coalición o agrupación de electores con infracción de lo dispuesto en el artículo 5.Uno de la Ley Orgánica 8/2007, de 4 de julio, sobre financiación de los partidos políticos.

2. Los hechos anteriores serán castigados con una pena de prisión de seis meses a cuatro años y multa del triplo al quíntuplo de su valor o del exceso cuando:

a) Se trate de donaciones recogidas en el artículo 5.Uno, letras a) o c) de la Ley Orgánica 8/2007, de 4 de julio, sobre financiación de los partidos políticos, de importe superior a 500.000 euros, o que superen en esta cifra el límite fijado en la letra b) del aquel precepto, cuando sea ésta el infringido.

b) Se trate de donaciones recogidas en el artículo 7.Dos de la Ley Orgánica 8/2007, de 4 de julio, sobre financiación de los partidos políticos, que superen el importe de 100.000 euros.

3. Si los hechos a que se refiere el apartado anterior resultaran de especial gravedad, se impondrá la pena en su mitad superior, pudiéndose llegar hasta la superior en grado.

4. Las mismas penas se impondrán, en sus respectivos casos, a quien entregare donaciones o aportaciones destinadas a un partido político, federación, coalición o agrupación de electores, por sí o por persona interpuesta, en alguno de los supuestos de los números anteriores.

5. Las mismas penas se impondrán cuando, de acuerdo con lo establecido en el artículo 31 bis de este Código, una persona jurídica sea responsable de los hechos. Atendidas las reglas es- 
tablecidas en el artículo 66 bis, los jueces y tribunales podrán asimismo imponer las penas recogidas en las letras b) a g) del apartado 7 del artículo 33. núm. 4):

\section{Propuesta Grupo Parlamentario Socialista (Enmienda}

1. Será castigado con las penas de multa del triplo al séxtuplo de la cantidad recibida, e inhabilitación especial para empleo o cargo público, profesión u oficio y derecho de sufragio pasivo de cuatro a diez años el que reciba donaciones o aportaciones destinadas a un partido politico, federación, coalición o agrupación de electores con infracción de lo dispuesto en el artículo 5. Uno de la Ley Orgánica 8/2007, de 4 de julio, sobre financiación de partidos políticos.

2. Los hechos anteriores serán castigados con penas de prisión de dos a cuatro años y, además, las penas previstas en el apartado anterior en su mitad superior cuando:

a) Se trate de donaciones recogidas en el artículo 5.Uno, letras a) o c) de la Ley Orgánica 8/2007, de 4 de julio, sobre financiación de los partidos políticos, de importe superior a 250.000 euros.

b) Se trate de donaciones recogidas en el artículo 7.Dos de la Ley Orgánica 8/2007, de 4 de julio, sobre financiación de los partidos políticos, que superen el importe de 50.000 euros.

3. A quien entregare donaciones o aportaciones destinadas a un partido político, federación, coalición o agrupación de electores, por sí o por persona interpuesta, en alguno de los supuestos de los apartados 1 y 2 anteriores, además de las penas previstas en sus respectivos casos, se le podrá imponer la pérdida de la posibilidad de obtener subvenciones o ayudas públicas y del derecho beneficios o incentivos fiscales o de la Seguridad Social durante el período de tres a seis años, así como la imposibilidad de contratar con las administraciones públicas por el mismo período.

4. En las infracciones a que se refieren los apartados anteriores de este artículo, cuando resultaran de especial grave- 
dad, el Juez o Tribunal podrá, excepcionalmente, imponer la pena superior en grado a la prevista.

5. Cuando, de acuerdo con lo establecido en el artículo 31 bis de este Código, una persona jurídica sea responsable de los hechos, se le impondrá la pena de multa de uno a cinco años. Atendidas las reglas establecidas en el artículo 66 bis, los jueces y tribunales podrán asimismo imponer las penas recogidas en las letras b) a g) del apartado 7 del artículo 33.

6. Cuando, de acuerdo con lo establecido en el artículo 129 de este Código, una empresa, organización, grupo o cualquier otra clase de entidad o agrupación de personas que, por carecer de personalidad jurídica, no estén comprendidas en el artículo 31 bis, sea responsable de los hechos, se le impondrá una o varias consecuencias accesorias a la pena que corresponda al autor del delito, con el contenido previsto en las letras c) a g) del apartado 7 del artículo 33. Podrá también acordar la prohibición definitiva de llevar a cabo cualquier actividad, aunque sea lícita.

En primer lugar, respecto del apartado primero, la pena de multa para la persona física pasaría de ser del triplo al quíntuplo de su valor a multa del triplo al séxtuplo. Incremento que a nuestro juicio es del todo innecesario, pues, consideremos que la actual cuantía que se fija para la pena pecuniaria ya es elevada. Con todo, cierto es que, por ejemplo, delitos con los que se podría establecer cierta comparación (por su similar grado de lesividad) como los de fraude fiscal (art. $305 \mathrm{CP}$ ), fraude a la seguridad social (arts. 307 y ss. CP) y fraude de subvenciones (art. $308 \mathrm{CP}$ ) establecen dicho límite del séxtuplo. Por otro lado, se propone incorporar la pena de inhabilitación especial para empleo o cargo público, profesión u oficio y derecho de sufragio pasivo de cuatro a diez años, lo cual, en nuestra opinión, debería recalibrarse en caso de que dicha pena se estimase oportuna, dado que nos parece desproporcionado tanto el límite inferior como el superior. 
En cambio, en dicha propuesta no desaparece la desafortunada remisión que el apartado primero y también el segundo del art. 304 bis CP efectúan a la LOFPP. De forma que el texto legal no disiparía la confusión a que se prestan ambos preceptos, aun cuando sería conveniente: ¿significa ello que las irregularidades relacionadas con la financiación electoral quedan al margen del art. 304 bis CP? Así lo ha entendido determinado sector que considera que también la LOREG prevé determinadas infracciones en materia de financiación electoral y, en cambio, el Código Penal no alude a ellas ${ }^{10}$. De seguir esta interpretación, una donación hecha por una persona jurídica a un partido para fines electorales, cualquiera que fuere su importe, sería atípica. En cambio, la misma donación destinada a gastos ordinarios del partido sería constitutiva de delito. De igual forma, la donación realizada por una persona física en los siguientes términos: 2.000 euros para gastos electorales y 49.000 euros para gastos de normal funcionamiento del partido, no sería delictiva, aun superando el límite de 50.000 euros anuales. En igual sentido, la donación hecha por un Gobierno extranjero por importe de 2.000.000 euros para financiar la campaña electoral de una formación política no supondría una infracción del art. 304 bis CP, aun cuando supera claramente el límite de los 100.000 euros.

Por ello, a nuestro juicio, la desafortunada remisión del art. 304 bis CP a la LOFPP debe entenderse hecha sólo al tipo o clase de donaciones a las que aluden los arts. 5.1 y 7.2 LOFPP, y no a su ámbito objetivo de aplicación que, por otro lado, no sólo se circunscribe a la financiación ordinaria, pues, también en ella se contemplan previsiones, por ejemplo, en materia de superación de gastos electorales. De forma que, en nuestra opinión, el art. 304 bis CP no estaría estableciendo ninguna distinción entre ambos tipos de financiación: electoral y ordinaria. Aunque lo preferible para evitar confusiones sería, como proponemos, que la remisión efectuada a la LOFPP desapareciera del art. 304 bis CP.

10 Vid., por todos, MUÑOZ CONDE, F.: Derecho penal. Parte especial, Valencia, Tirant lo Blanch, 2017, p. 486.

Estudios Penales Y Criminológicos vol. XXXIX (2019). ISSN 1 137-7550: 541-591 -548- hitp://dx.doi.org/10.15304/epc.39.6066 
Aun así, debe matizarse que el art. 129 LOREG permite a las personas jurídicas aportar hasta 10.000 euros a las cuentas abiertas por un mismo partido para recaudar fondos en las elecciones convocadas. Por lo que, en este caso, de seguir la interpretación que hemos propuesto más arriba, sólo deberían considerarse delictivas dichas aportaciones cuando superasen aquella cifra ${ }^{11}$. Con todo, y ello restaría validez a nuestra postura, lo cierto es que a pesar de la literalidad de ese precepto, la Junta Electoral Central en su Acuerdo 134/2017, de 4 de diciembre, manifestó que «la previsión establecida en el artículo 129 de la LOREG, según la cual las formaciones políticas pueden (con un limite de 10.000 euros) recibir donaciones provenientes de personas jurídicas para recaudar fondos en las elecciones convocadas, es una previsión que debe entenderse inaplicable en tanto permanezca en vigor la prohibición que se ha incluido en la Ley Orgánica 8/2007, de 4 de julio, sobre financiación de los partidos políticos, cuyo vigente artículo 5 dispone que: "Los partidos políticos no podrán aceptar o recibir directa o indirectamente: (...) c) Donaciones procedentes de personas jurídicas y de entes sin personalidad jurídica" ${ }^{12}{ }^{12}$. A pesar de ello, debemos traer a colación el voto particular emitido por los vocales Doña María del Pilar Teso Gamella, Don Antonio Jesús Fonseca-Herrero Raimundo y Doña Inés Olaizola Nogales, al acuerdo mayoritario de la JEC, que puede resumirse de la forma que sigue: «en la resolución de la que discrepamos (...) en realidad lo que se sostiene es que sigue vigente pero sólo resulta aplicable a las personas fisicas, lo que representa, o se parece mucho, a una suerte de modificación legislativa». No podemos estar más de acuerdo con lo expresado de forma tan gráfica en esta última afirmación contenida en el voto particular. En este sentido, el tenor literal del art. 129 LOREG no deja margen para la duda: las personas jurídicas sí pueden contribuir a la financiación de los gastos electorales con el límite de 10.000 euros. Por lo que

11 LEÓN ALAPONT, J.: La responsabilidad..., op. cit., pp. 365-367.

12 Dicha conclusión es acogida también en el posterior Acuerdo de la JEC 104/2018, de 29 de noviembre. 
la resolución de la JEC se aparta y mucho de lo establecido en dicho precepto.

En segundo lugar, el apartado segundo recogería igualmente (como sucede ahora) las modalidades agravadas, sin embargo, la pena de prisión pasaría a ser de dos a cuatro años (con los efectos que ello tendría a la hora de obtener la suspensión de la pena), cuando con la redacción vigente es de seis meses a cuatro años. Este sería quizá el único aspecto criticable, pues, en principio, no parece descabellado establecer una pena de prisión de dos a cuatro años para supuestos "agravados" cuando podemos encontrar otros delitos de contenido económico (como el fraude fiscal) en los que el tipo básico ya se castiga con una pena de 1 a 5 años (art. 305.1 CP). No obstante, debe matizarse que conforme a la propuesta de reforma que más adelante se presentará (vid. infra III.4) deberían ser otros los supuestos de financiación ilegal sancionados con pena privativa de libertad y no los que se regulan en el citado precepto. Además, cabe tener en cuenta que también se permitiría que las otras penas contempladas en el apartado primero (multa, inhabilitación especial para empleo o cargo público, profesión u oficio y derecho de sufragio pasivo) se impusieran en su mitad superior.

Ahora bien, las modificaciones relativas a este segundo apartado afectan también a las cuantías a partir de las cuales se considera que las conductas entrañan mayor desvalor. Así, con la regulación propuesta, cuando se tratase de donaciones recogidas en el artículo 5.Uno, letras a) o c) de la Ley Orgánica 8/2007, de 4 de julio, sobre financiación de los partidos políticos, el importe debería ser superior a 250.000 euros. Antes se cifraba en 500.000 euros (en esos dos supuestos). Precisamente, es aquí donde advertimos una sustancial novedad: no se contempla en la propuesta el supuesto de la letra b) del art. 5.1 LOFPP, de forma que las donaciones hechas por personas físicas en cómputo anual, asciendan a la cuantía que sea, no comportarían pena de prisión, a diferencia de lo que sucede con la regulación vigente al superar los 550.000 euros. Por otro lado, cuando se tratase de 
donaciones recogidas en el artículo 7.Dos de la Ley Orgánica $8 / 2007$, de 4 de julio, sobre financiación de los partidos políticos, éstas serían delictivas si superasen los 50.000 euros (antes se fijaba en 100.000 euros).

En relación con la exclusión de las donaciones de personas físicas del tipo agravado del art. 304 bis CP, las dos razones que creemos pueden subyacer son: 1) la de considerar que los focos de financiación en la práctica más habituales sean los seleccionados: donaciones anónimas, condicionales (finalistas y revocables) y, sobre todo, de empresas; $y, 2$ ) la de entender que sólo ese tipo de aportaciones son las más lesivas y de ahí que deban tener una modalidad agravada. Cabría añadir una tercera posibilidad mucho más simple: la de haber olvidado copiar la última parte del artículo en su redacción vigente al confeccionar la enmienda. En cualquier caso, sea cual fuere la intención, deben hacerse las siguientes consideraciones: por un lado, no creemos que ese tipo de donaciones se deban excluir (siguiendo la lógica del precepto) del sistema agravado cuando éste se fija con base en límites cuantitativos; y, por otro lado, que de mantener la redacción actual, el legislador debiera optar por un tipo agravado que pudiera a su vez distinguir entre dos niveles: uno con una penalidad menor hasta alcanzar una cifra (por ejemplo, los 250.000 y 50.000 euros respectivamente) y otro con una penalidad mayor (los actuales 500.000 y 100.000 euros respectivamente) lo cual dotaría al precepto de mayor proporcionalidad.

En cuanto al tercer apartado, que regula la entrega de donaciones o aportaciones, se contempla como novedoso la posibilidad de imponer a la persona física, además de las penas previstas en sus respectivos casos, la pérdida de la posibilidad de obtener subvenciones o ayudas públicas y del derecho a gozar de beneficios o incentivos fiscales o de la Seguridad Social durante el período de tres a seis años, así como la imposibilidad de contratar con las administraciones públicas por el mismo período. A nuestro juicio, una previsión de este tipo resulta acertada: en primer lugar, porque es una previsión que se contiene en nume- 
rosos ejemplos a lo largo del Código Penal (podríamos citar los arts. 305, 424 o $429 \mathrm{CP}$ ); y, en segundo lugar, por su utilidad según el caso a efectos de prevención especial (piénsese, a título ilustrativo, en el empresario que tras haber donado determinada cantidad al partido por haber conseguido un importante contrato de la Administración, se le prohíbe contratar con ésta).

Por cuanto respecta al apartado cuarto, se prevé que cuando las conductas descritas en los apartados anteriores resultaran de especial gravedad, el Juez o Tribunal podrá, excepcionalmente, imponer la pena superior en grado a la prevista. Esta regla se prevé en la regulación vigente, pero, no es potestativa, sino imperativa, estando el juez o tribunal obligado a imponer la pena en su mitad superior, pudiéndose llegar hasta la superior en grado. Por ello, la modificación nos parece oportuna, esto es, la imposición de la pena superior en grado tiene que ser algo extraordinario y no tendrá que darse en todos aquellos casos en que se considere que los hechos revisten especial gravedad. A pesar de lo anterior, y si bien es cierto que el Código Penal está repleto de cláusulas de este estilo ${ }^{13}$, se trata de una circunstancia que dependerá de la valoración que su señoría realizase arreglo a su leal saber y entender con la inseguridad jurídica que ello genera. Ahora bien, como ha puesto de relieve la doctrina, el principal problema que genera este precepto es el amplio margen de discrecionalidad del que disfrutan jueces y tribunales a la hora de delimitar qué debe entenderse por "conductas de especial gravedad"14. Con el añadido de que este apartado alcanza no sólo a los supuestos agravados sino a los tipos básicos.

13 Podrían citarse como ejemplo los arts. 51, 52, 80,89, 90, 270, 305 o 307 CP.

14 A pesar de la imprecisión de dicha expresión, algunos autores han convenido en que para que unos hechos resulten de especial gravedad deberán valorarse, entre otros, aspectos tales como la relevancia económica de la conducta delictiva, las condiciones en que tiene lugar la donación, las circunstancias inherentes al autor del delito o la especial finalidad perseguida por el donante. Vid., por ejemplo, MORALES HERNÁNDEZ, M. Á.: "Los delitos de financiación ilegal de los partidos políticos”, en MARÍN DE ESPINOSA CEBAllos, E. M. (Dir.): Lecciones de Derecho Penal. Parte Especial, Valencia, Tirant lo Blanch, 2018, pp. 263-264. 
En referencia al apartado quinto, éste prevé el castigo de la persona jurídica que sea responsable, conforme al art. 31 bis $\mathrm{CP}$, de los hechos descritos en el citado precepto. Por tanto, este apartado abarca básicamente tres situaciones: a) la de la empresa que, por ejemplo, con parte de sus recursos realiza donaciones a un determinado partido; b) la de la empresa que actúa como intermediaria recibiendo donaciones que van a ir destinadas a un partido; y, c) la del propio partido que recibe finalmente los fondos. Pues bien, si con la regulación vigente la pena de multa a imponer es del triple al quíntuplo, la propuesta de reforma contempla una pena de multa de uno a cinco años (por tanto, se produce un cambio del sistema proporcional al de días-multa). Manteniéndose incólume la cláusula "atendidas las reglas establecidas en el artículo 66 bis, los jueces y tribunales podrán asimismo imponer las penas recogidas en las letras b) a g) del apartado 7 del artículo 33". Con todo, debe apreciarse que, ni la actual regulación ni la contenida en esta propuesta, prevén (para la persona jurídica) una pena distinta según la gravedad de los hechos, extremo este que debiera ser corregido por el legislador.

Por último, el apartado sexto incluye una disposición similar a la anterior, pero, en esta ocasión, dirigida a los entes sin personalidad jurídica. Si bien, sólo se les podría imponer una o varias consecuencias accesorias a la pena que corresponda al autor del delito, con el contenido previsto en las letras c) a g) del apartado 7 del artículo 33. Pudiéndose también acordar la prohibición definitiva de llevar a cabo cualquier actividad, aunque sea lícita.

\section{Crítica doctrinal al vigente art. 304 bis CP.}

Para algunos autores, el legislador español sólo se ha centrado, a la hora de configurar el delito de financiación ilegal de partidos, en los fondos o aportaciones que éstos reciben, esto es, únicamente en la vertiente de los ingresos que obtiene el partido y no en el ahorro de costes con los que también se puede financiar (ilegalmente) al partido ${ }^{15}$. De forma que, por

15 Así lo han destacado, entre otros, BASSO, G. J.: "Delitos de financiación ilegal de los partidos políticos", en MOLINA FERNÁNDEZ, F. (Coord.): 
ejemplo, será delito que una empresa done 25.000 euros a un partido, pero no que sufrague los gastos de la campaña electoral de esa formación. Además, no distingue el art. 304 bis CP entre donaciones de procedencia lícita o ilícita, por lo que dará igual, por ejemplo, que los 60.000 euros entregados por un particular provengan de una estafa que se trate de dinero que éste haya obtenido lícitamente.

Por otro lado, la doctrina cuestiona también que no quede abarcada por el art. 304 bis CP la obtención de financiación ilícita de origen público ${ }^{16} \mathrm{o}$ las donaciones de bienes inmuebles hechas por personas físicas, que no quedan sujetas a límite cuantitativo alguno (a diferencia de lo que sucede con la restricción de los 50.000 euros anuales) ${ }^{17}$. Así, tampoco se ha entendido (siguiendo la lógica adoptada por el legislador) por qué otras infracciones de la LOFPP no son consideradas delictivas, como por ejemplo: las condonaciones de deuda por parte de entidades de crédito $^{18}$ y las donaciones de personas físicas con contrato vigente con la administración pública ${ }^{19}$.

Penal 2017, Madrid, Francis Lefebvre, 2016, p. 1401. GONZÁLEZ GUGEL, J.: "Financiación ilegal de partidos políticos", en AYALA GÓMEZ, I. y ORTIZ DE URBINA GIMENO, I. (Coords.): Penal económico y de la empresa 2016-2017, Madrid, Francis Lefebvre, 2016, p. 725. Y SÁINZCANTERO CAPARRÓS, J. E.: "Los delitos de financiación ilegal de partidos políticos", en MORILLAS CUEVAS, L. (Dir.): Sistema de Derecho Penal. Parte Especial, Madrid, Dykinson, 2016, p. 792.

16 En este sentido se han pronunciado, por ejemplo, BUSTOS RUBIO, M.: "El nuevo delito de financiación ilegal de partidos políticos", Revista Penal, núm. 37, 2016, p. 64. Y VERA SÁNCHEZ, J. S.: "Financiación ilegal de los partidos políticos (arts. 304 bis-304 ter)", en CORCOY BIDASOLO, M. y GÓMEZ MARTÍN, V. (Dirs.): Manual de Derecho penal, económico y de empresa. Parte general y Parte especial Tomo II, Valencia, Tirant lo Blanch, 2016, p. 368.

17 Vid., a título ilustrativo, MAROTO CALATAYUD, M.: "Financiación ilegal de partidos políticos", en QUINTERO OLIVARES, G. (Dir.): Comentario a la reforma penal de 2015, Cizur Menor, Thomson Reuters-Aranzadi, 2015, p. 762.

18 En este sentido, QUINTERO OLIVARES, G.: “Artículo 304 bis...”, op. cit., p. 531.

19 Así, por ejemplo, OLAIZOLA NOGALES, I.: “«Medidas de regeneración democrática». La nueva regulación de la financiación de los partidos políticos en España”, Estudios de Deusto, vol. 63, núm. 1, 2015, p. 350. 
Pero, sin duda, el aspecto más polémico que ha captado la atención de la doctrina es el referente a la no inclusión de las fundaciones y asociaciones vinculadas a los partidos en el ámbito subjetivo del art. 304 bis CP. En este sentido, la Disposición Adicional séptima LOFPP permite que éstas puedan recibir donaciones de personas físicas, jurídicas o entes sin personalidad jurídica sin atender a las restricciones establecidas en el art. 5 a) y b) LOFPP. De forma que, si bien las donaciones efectuadas a un partido por sus fundaciones o asociaciones vinculadas serían constitutivas de un delito de financiación ilegal (pues se trata de donaciones hechas por personas jurídicas), no sucederá lo mismo respecto de la asunción de gastos del partido por parte de éstas. Incluso, la citada norma expresa que no tendrán la consideración de donaciones las entregas monetarias o patrimoniales realizadas por una persona física o jurídica para financiar "una actividad o un proyecto concreto de la fundación o entidad". De ahí que, los "convenios de colaboración" suscritos entre los partidos políticos y las respectivas fundaciones puedan ocultar auténticas donaciones. Ello constituye, sin duda, una auténtica "válvula de escape" que permite sortear a los partidos las limitaciones impuestas a su financiación ${ }^{20}$.

Con todo, como puede apreciarse, los grupos parlamentarios parecen no haber tenido en cuenta estas críticas a la hora de plantear sus propuestas de reforma del art. 304 bis CP.

\section{En relación con el art. 304 ter CP}

\section{Actual redacción:}

1. Será castigado con la pena de prisión de uno a cinco años, el que participe en estructuras u organizaciones, cualquiera que sea su naturaleza, cuya finalidad sea la financiación de partidos politicos, federaciones, coaliciones o agrupaciones de electores, al margen de lo establecido en la ley.

20 En este sentido, SANTANA VEGA, D. M.: "El delito de financiación ilegal de partidos políticos", en QUERALT JIMÉNEZ, J. y SANTANA VEGA, D. M. (Dirs.): Corrupción pública y privada en el Estado de Derecho, Valencia, Tirant lo Blanch, 2017, p. 137. 
2. Se impondrá la pena en su mitad superior a las personas que dirijan dichas estructuras $u$ organizaciones.

3. Si los hechos a que se refieren los apartados anteriores resultaran de especial gravedad, se impondrá la pena en su mitad superior, pudiéndose llegar hasta la superior en grado.

El legislador configuró en 2015 a través de este precepto una nueva figura asociativo-delictiva sui generis, por cuanto a la vez que guarda cierta semejanza con la asociación ilícita (art. $515.1 \mathrm{CP}$ ) y la organización criminal (art. 570 bis CP), presenta algunas notas propias. Veamos cuáles son unas y otras:

a) El tenor literal del precepto es similar al de los arts. 515.1 y 570 bis CP.

\section{Artículo 515}

Son punibles las asociaciones ilícitas, teniendo tal consideración:

1. ${ }^{\circ}$ Las que tengan por objeto cometer algún delito o, después de constituidas, promuevan su comisión.

\section{Artículo 570 bis}

1. (...) A los efectos de este Código se entiende por organización criminal la agrupación formada por más de dos personas con carácter estable o por tiempo indefinido, que de manera concertada y coordinada se repartan diversas tareas o funciones con el fin de cometer delitos.

b) Obsérvese que en el actual art. 304 ter CP sólo se castiga a quienes participen y a quienes dirijan las estructuras $\mathrm{u}$ organizaciones que tengan por finalidad financiar a partidos políticos, federaciones, coaliciones o agrupaciones de electores.

En la asociación ilícita se sanciona a los fundadores, directores, presidentes de las asociaciones, y a los miembros activos (art. $517 \mathrm{CP}$ ). Así como a quienes cooperen económicamente o de cualquier otra clase (art. $518 \mathrm{CP}$ ).

Por su parte, el art. 570 bis $1 \mathrm{CP}$ sanciona a quienes promovieren, constituyeren, organizaren, coordinaren o 
dirigieren una organización criminal. Y a quienes participaren activamente en la organización, formaren parte de ella o cooperaren económicamente o de cualquier otro modo con la misma.

c) Las penas establecidas para las personas físicas en los tres preceptos son dispares.

d) No permite adoptar la disolución de dichas "estructuras" u "organizaciones" como sí sucede en el caso de la asociación ilícita (art. 520 CP) y la organización criminal (art. 570 quater $\mathrm{CP}$ ).

e) Pero, la diferencia principal es que el apartado primero del art. 304 ter CP alude a que las estructuras u organizaciones tengan por finalidad la financiación de partidos políticos, federaciones, coaliciones o agrupaciones de electores, al margen de lo establecido en la ley, lo que a priori parece abarcar no sólo la comisión de conductas delictivas (las del art. 304 bis CP) sino también la infracción de normas administrativas (como las previstas en la LOFPP y la LOREG). A diferencia de lo que sucede en los arts. $515.1 \mathrm{CP}$ y 570 bis $\mathrm{CP}$ que hacen referencia a la comisión de delitos.

A nuestro juicio, el vigente art. 304 ter CP alberga una modalidad de organización criminal ${ }^{21}$, a saber, la de estructuras u organizaciones (con o sin personalidad jurídica) que centren toda (o prácticamente toda) su actividad en la financiación de partidos políticos, federaciones, coaliciones o agrupaciones de electores, al margen de lo dispuesto en la ley ${ }^{22}$. De forma que, la

21 En este sentido, el legislador ha optado por introducir un tipo específico referido a esta clase de organizaciones, al igual que en otras figuras delictivas como trata de seres humanos (177 bis CP), blanqueo de capitales (art. 302 $\mathrm{CP}$ ) o tráfico de drogas (art. $369 \mathrm{CP}$ ). Si bien, el art. 304 ter CP parece estar refiriéndose también al concepto de grupo criminal cuando hace alusión al término "estructuras".

22 Vid., respecto de la calificación de un partido político como organización criminal, LEÓN ALAPONT, J.: "La responsabilidad penal de los partidos políticos en España: ¿disfuncionalidad normativa?”, Revista General de Derecho Penal, núm. 27, 2017, pp. 22 y ss. 
empresa que, por ejemplo, compagine su actividad cotidiana (la de su objeto social) con la de financiar a una formación política de forma ilícita, no entraría dentro de este concepto que maneja el art. 304 ter CP, y sí encajaría en el apartado quinto del actual art. 304 bis CP.

Ahora bien, si como hemos afirmado, pudiera interpretarse que la expresión "al margen de lo establecido en la ley" abarca no sólo la comisión de conductas delictivas (las del art. 304 bis $\mathrm{CP}$ ), sino también la infracción de normas administrativas (como las previstas en la LOFPP y la LOREG), entendemos que no se debería elevar a la categoría de delito el hecho de participar o dirigir estructuras u organizaciones en las que la totalidad (o prácticamente la totalidad) de su actividad se centrase en la financiación de partidos políticos, federaciones, coaliciones o agrupaciones de electores, cuando únicamente se incurriese en infracciones administrativas. A estos efectos, habría que considerar que con la expresión "al margen de lo establecido en la ley" el Código se refiere a la Ley penal, de forma que cabría hacer una interpretación restrictiva del término ley.

Propuesta Grupo Parlamentario Mixto:

El artículo único del que constaba la Proposición de Ley Orgánica sobre represión penal de la financiación ilegal de los partidos políticos, añadía un apartado 4 al artículo 304 ter de la LO 10/1995, de 23 de noviembre, del Código Penal, de forma que quedare redactado como sigue:

4. Cuando, de acuerdo con lo establecido en el artículo 31 bis de este Código, una persona jurídica sea responsable de los hechos, se le impondrá la pena de multa de uno a cinco años. Atendidas las reglas establecidas en el artículo 66 bis, los jueces y tribunales podrán asimismo imponer las penas recogidas en las letras b) a g) del apartado 7 del artículo 33 .

Con este nuevo apartado se lograría suplir la deficiencia anteriormente comentada, la de que con el actual art. 304 ter $\mathrm{CP}$ no se puede imponer consecuencia jurídica alguna sobre 
las "estructuras" u "organizaciones" que tuviesen por finalidad la financiación de partidos políticos, federaciones, coaliciones o agrupaciones de electores, al margen de lo establecido en la ley. No obstante, consideramos que la pena a imponer, dado que estamos ante una especie de organización criminal, debiera ser la disolución (en coherencia con el art. 570 quater CP), y no la pena de multa de uno a cinco años (junto con la posibilidad de que atendidas las reglas establecidas en el artículo 66 bis, los jueces y tribunales puedan asimismo imponer las penas recogidas en las letras b) a g) del apartado 7 del artículo 33).

Ahora bien, como se refleja en la exposición de motivos que se acompaña a la proposición de ley orgánica, la intención del Grupo Parlamentario Mixto con la inclusión de esta cláusula era la siguiente:

“(...) el artículo 304 ter castiga al que participe en estructuras u organizaciones, cualquiera que sea su naturaleza, cuya finalidad sea la financiación de partidos políticos, federaciones, coaliciones o agrupaciones de electores, al margen de lo establecido en la ley, si bien la previsión legal no alcanza en este supuesto a conferir a Jueces y Tribunales la potestad para decretar también la disolución o suspensión de actividades del partido político que eventualmente pudiese haber promovido tal conducta o haberse beneficiado de ella.

Existe, pues, un vacio legal que permite la continuidad de aquellas organizaciones politicas que probadamente se hubieren beneficiado de la actividad de estructuras montadas en su seno al objeto de procurarles financiación por vías ilegales, aunque se castiga a las personas que integrasen dichas estructuras y más gravemente a quienes las dirigiesen. Tal situación supone un déficit en la tutela penal a la que tiene derecho la ciudadania para salvaguardarse de aquellas actuaciones que en materia de financiación ilegal de los partidos políticos resultan más perjudiciales para la salud democrática de nuestro Estado, a saber, aquellas no cometidas por individuos aislados sino por redes organizadas por los propios partidos como fuente continuada de ingresos que les permite desplegar un nivel de actividad por encima de sus posibilidades y adquirir así ilí- 
citamente una posición de clara ventaja sobre las formaciones políticas que ajustan su financiación a los parámetros legales".

En cambio, tenemos serias dudas de que del tenor literal del nuevo apartado cuarto del art. 304 ter CP pudiera deducirse que las penas previstas en él pudieran decretarse sobre un partido político, ya que no se alude en ningún momento a si esa estructura u organización ha sido creado por el propio partido, es controlada por éste, o existe algún tipo de dependencia o vínculo entre ambos. En este sentido, consideramos que la propuesta que más adelante valoraremos del Grupo Parlamentario Popular es la más acertada para cubrir dicho supuesto.

\section{Propuesta Grupo Parlamentario Ciudadanos (Enmienda} núm. 3):

Se modifica el artículo 304 ter, que queda redactado como sigue:

1. Será castigado con la pena de prisión de uno a cinco años, el que participe en estructuras u organizaciones, cualquiera que sea su naturaleza, cuya finalidad sea la financiación de partidos políticos, federaciones, coaliciones o agrupaciones de electores, al margen de lo establecido en la ley.

2. Se impondrá la pena en su mitad superior a las personas que dirijan dichas estructuras u organizaciones.

3. Si los hechos a que se refieren los apartados anteriores resultaran de especial gravedad, se impondrá la pena en su mitad superior, pudiéndose llegar hasta la superior en grado. Además, el juez deducirá testimonio, que remitirá al Gobierno y al Ministerio Fiscal a los efectos de que se inicie el procedimiento de disolución judicial del partido político previsto en los artículos 10, 11 y 12 de la Ley Orgánica 6/2002, de 27 de junio, de Partidos Políticos.

4. Cuando, de acuerdo con lo establecido en el artículo 31 bis de este Código, una persona jurídica sea responsable de los hechos, se le impondrá la pena de multa de uno a cinco años. Atendidas las reglas establecidas en el artículo 66 bis, los jueces y tribunales podrán asimismo imponer las penas recogidas en las letras b) a g) del apartado 7 del artículo 33. 
De la propuesta del Grupo Parlamentario de Ciudadanos, nos centraremos en comentar la reforma que se propone del actual apartado tercero del art. 304 ter CP. Así, se plantea que cuando los hechos a que se refieren los apartados anteriores resultaran de especial gravedad, "el juez deducirá testimonio, que remitirá al Gobierno y al Ministerio Fiscal a los efectos de que se inicie el procedimiento de disolución judicial del partido político previsto en los artículos 10,11 y 12 de la Ley Orgánica 6/2002, de 27 de junio, de Partidos Políticos". De forma que, al ya de por sí impreciso término "de especial gravedad", se suma el hecho de que en ese caso el juez tenga que decretar la disolución del partido, sin que haya un presupuesto habilitante para imponer dicha pena. Y digo que no hay presupuesto habilitante, ni en dicho apartado ni en ningún otro del articulado propuesto porque, insisto, no se exige ningún nexo de conexión entre quien financia a la formación política y ésta. Por tanto, a nuestro juicio, se estaría haciendo responsable al partido político con base en meras presunciones, lo cual resulta del todo rechazable. núm. 4):

Propuesta Grupo Parlamentario Socialista (Enmienda

1. Será castigado con las penas de prisión de dos a seis años y multa del tanto a séxtuplo de la cantidad recibida, e inhabilitación especial para empleo o cargo público, profesión u oficio y derecho de sufragio pasivo de cuatro a diez años, el que participe en estructuras u organizaciones, cualquiera que sea su naturaleza, cuya finalidad sea la financiación de partidos políticos, federaciones, coaliciones o agrupaciones de electores, al margen de lo establecido en la ley.

2. Se impondrá la pena en su mitad superior a las personas que dirijan dichas estructuras u organizaciones.

3. Si los hechos a que se refieren los apartados anteriores resultaran de especial gravedad, se impondrá la pena en su mitad superior, pudiéndose llegar hasta la superior en grado.

4. Cuando, de acuerdo con lo establecido en el artículo 31 bis de este Código, una persona jurídica sea responsable de los hechos, se le impondrá la pena de multa de uno a cinco 
años. Atendidas las reglas establecidas en el artículo 66 bis, los jueces y tribunales podrán asimismo imponer las penas recogidas en las letras b) a g) del apartado 7 del artículo 33 .

5. Cuando, de acuerdo con lo establecido en el artículo 129 de este Código, una empresa, organización, grupo o cualquier otra clase de entidad o agrupación de personas que, por carecer de personalidad jurídica, no estén comprendidas en el artículo 31 bis, sea responsable de los hechos, se le impondrá una o varias consecuencias accesorias a la pena que corresponda al autor del delito, con el contenido previsto en las letras c) a g) del apartado 7 del artículo 33. Podrá también acordar la prohibición definitiva de llevar a cabo cualquier actividad, aunque sea lícita.

Comenzando por el apartado primero del nuevo artículo 304 ter CP, debemos mostrar nuestra frontal oposición al incremento de la pena de prisión prevista para dichos supuestos, que pasaría de ser de uno a cinco años, a una pena de prisión de dos a seis años. A este respecto debe tenerse en cuenta que, por ejemplo, el art. 570 bis $1 \mathrm{CP}$ establece una pena de prisión de 1 a 3 años para quien participe activamente en la organización cuando ésta tenga como fin la comisión de delitos que no sean graves y, con la actual regulación, los delitos de financiación no pueden ser calificados como graves a tenor de lo dispuesto en el art. 33.2 CP. En este sentido, la actual regulación del art. 304 ter CP ya parece desproporcionada en comparación con el art. 570 bis $1 \mathrm{CP}$. No obstante, la propuesta del PSOE de incremento de la pena de prisión de dos a seis años se entiende por cuanto está en coherencia con la modificación planteada del art. 304 bis CP: al establecerse la pena de inhabilitación especial para empleo o cargo público, profesión u oficio y derecho de sufragio pasivo de cuatro a diez años, el delito de financiación ilegal pasaría a tener la consideración de grave -art. 33.2 d) $\mathrm{CP}$-, pero es que aun así no entraría dentro de la horquilla que el art. 570 bis $1 \mathrm{CP}$ contempla para quien participe activamente en la organización cuando ésta tenga como fin la comisión de delitos graves (que es de 2 a 5 años). Por el contrario, que se quiera establecer junto a 
la pena de prisión, otras penas como la de multa e inhabilitación especial para empleo o cargo público, profesión u oficio y derecho de sufragio pasivo, nos parece razonable.

Ahora bien, el principal escollo a sortear en este apartado, que es de técnica jurídica, refiere al establecimiento de una multa proporcional (del tanto al séxtuplo de la cantidad recibida), cuando lo preferible hubiere sido fijar una multa por cuotas. Al no suceder esto último, entendemos que será difícil cifrar la cuantía de la multa con respecto de la cuantía recibida. En primer lugar, porque ello implicaría que la "estructura" u "organización" que financia debería, a su vez, recibir recursos con destino a una formación política (y no tiene por qué suceder así) $\mathrm{y}$, en segundo lugar, porque quien recibiese la financiación no tendría por qué ser necesariamente el partícipe (que es a quien se le va a imponer la multa).

Respecto del apartado quinto, nuestra valoración debe ser positiva, pues, naturalmente, la estructura u organización que financie a un partido, federación, coalición o agrupación de electores, puede carecer de personalidad jurídica. Así, con la aplicación del art. $129 \mathrm{CP}$, dicho espacio quedaría cubierto. Es más, una previsión así podría incluirse también en el art. 304 bis CP que sólo alude a personas jurídicas (31 bis CP).

Propuesta Grupo Parlamentario Popular (Enmienda núm. 5):

Se propone la supresión del artículo 304 ter, de la Ley Orgánica 10/1995, de 23 de noviembre, del Código Penal.

Propuesta Grupo Parlamentario Popular (Enmienda núm. 6):

Aunque se trate de la creación de un nuevo artículo, el 304 quater CP, ubicamos dicha propuesta de reforma en sede del art. 304 ter CP ya que, en realidad, es una reforma de éste.

1. Será castigado con la pena de prisión de uno a cinco años, el que participe en estructuras u organizaciones, cualquiera que sea su naturaleza, que se encuentren incardinadas de manera estable y permanente, dependan, mantengan un 
vínculo de conexión o hayan sido creadas por los partidos políticos, federaciones, coaliciones o agrupaciones de electores, cuya finalidad sea la financiación de dichos partidos políticos, federaciones, coaliciones o agrupaciones de electores, al margen de lo establecido en la ley.

2. Se impondrá la pena en su mitad superior a las personas que dirijan dichas estructuras u organizaciones dentro de los partidos políticos, federaciones, coaliciones o agrupaciones de electores, de acuerdo con sus normas internas de funcionamiento, ya sea una dirección de hecho o de derecho.

3. Si los hechos a que se refieren los apartados anteriores resultaran de especial gravedad, se impondrá la pena en su mitad superior, pudiéndose llegar hasta la superior en grado.

4. Cuando, de acuerdo con lo establecido en el artículo 31 bis de este Código, la persona jurídica, entendiendo por tal el partido político o federación, sea responsable de los hechos, se le impondrá la pena de multa de uno a cinco años. Atendidas las reglas establecidas en el artículo 66 bis, los jueces y tribunales podrán asimismo imponer las penas recogidas en las letras b) a g) del apartado 7 del artículo 33.

Respecto del apartado primero, como ya adelantamos, estimamos que esa es (de las propuestas) la fórmula que permitiría dotar de mayor autonomía a un precepto que no deja de ser una especie de organización criminal: cuando las estructuras $u$ organizaciones, cualquiera que sea su naturaleza, se encuentren incardinadas de manera estable y permanente, dependan, mantengan un vínculo de conexión o hayan sido creadas por los partidos políticos, federaciones, coaliciones o agrupaciones de electores. De lo contrario, este apartado podría ser prescindible dada la actual redacción e interpretación jurisprudencial del art. 570 bis CP. Ahora bien, no alcanzamos a entender por qué luego en el apartado cuarto la posibilidad de aplicar las penas en él previstas se circunscribe únicamente al caso de los partidos políticos y federaciones, y no a la "estructura" u "organización" que financie a éstos. 
En sentido similar, tampoco comprendemos que el apartado segundo contemple la imposición de la pena en su mitad superior sólo a las personas que dirijan dichas estructuras $\mathrm{u}$ organizaciones "dentro de los partidos políticos, federaciones, coaliciones o agrupaciones de electores, de acuerdo con sus normas internas de funcionamiento, ya sea una dirección de hecho o de derecho".

Por otro lado, en el apartado cuarto, se contempla con pena de multa la sanción del partido político (o federación) que cree un "entramado" para financiarse ilegalmente. Esta es una decisión que nos parece acertada, en tanto en cuanto ello no tiene porqué significar que toda la actividad del partido sea delictiva, lo que justificaría que se pudiera considerar en ese caso al partido político una organización criminal y, en consecuencia, poder disolverlo ${ }^{23}$. Lo que ya no nos parece tan acertado es, como advertimos anteriormente, que sólo se pueda castigar al partido o federación y no a la propia estructura u organización que financie ilegalmente a aquéllos. En este contexto, como tuvimos ocasión de señalar más arriba, a la estructura u organización que se dedique en exclusiva a financiar ilegalmente a un partido se la debería poder disolver por cuanto se asimilaría a una especie de organización criminal.

La doctrina, como más adelante comprobaremos, ha abogado por la supresión del art. 304 ter CP por considerar que su tipificación generaba una duplicidad con respecto del art. 570 bis CP. Sin embargo, y aun cuando podemos compartir dicha posición (el ente que se dedique en exclusiva a financiar ilegalmente a una formación política es una organización criminal), lo interesante de la propuesta del Partido Popular es que, con la actual redacción, no se puede atribuir responsabilidad penal al partido que genere de una u otra forma dichas "estructuras", sino solamente el hecho de financiarse en contra de lo dispuesto en el art. 304 bis CP.

23 Vid., con detalle, LEÓN ALAPONT, J.: "Partidos políticos y responsabilidad penal: una reflexión en torno al sistema de penas", Teoría y Derecho, núm. 25, 2019, pp. 223 y ss. 


\section{Crítica doctrinal al vigente art. 304 ter CP}

La principal crítica que la doctrina ha vertido sobre el art. 304 ter CP es que se trata de una previsión superflua ${ }^{24}$. Habiendo bastado con recurrir o bien a los tipos genéricos de organización y grupo criminal de los arts. 570 bis y 570 ter $\mathrm{CP}$ o bien al clásico delito de asociación para delinquir del art. $515 \mathrm{CP}^{25}$.

También se ha destacado que, aunque el art. 304 ter CP configure una modalidad específica de organización criminal, como sucede en otros preceptos (trata de seres humanos, blanqueo de capitales o tráfico de drogas), a diferencia de lo que allí sucede, en el presente supuesto la cualificación por pertenencia o dirección de la organización no se configura como una agravación de la pena para quien cometa el concreto delito (en nuestro caso, el de financiación ilegal), sino que se fija una pena autónoma (prisión de uno a cinco años). En consecuencia, la redacción de este precepto permite la apreciación de un concurso de delitos entre los arts. 304 bis CP y 304 ter CP con la excesiva penalidad que puede resultar de ello ${ }^{26}$.

Asimismo, se ha puesto de manifiesto que el tipo del art. 304 ter CP lleve aparejada una pena de prisión de uno a cinco años, que se impone en su mitad superior a los dirigentes de la organización y en la pena superior en grado para casos de especial gravedad, mientras que el tipo agravado de financiación ilegal del art. 304 bis 2 CP conlleva pena de prisión de seis meses a

24 Así, por ejemplo, HAVA GARCÍA, E.: "Financiación ilegal de partidos políticos", en TERRADILLOS BASOCO, J. M. (Coord.): Lecciones y materiales para el estudio del Derecho penal. Tomo III. Derecho penal parte especial. Volumen I, Madrid, Iustel, 2016, p. 456. QUINTERO OLIVARES, G.: “Artículo 304 bis...”, op. cit., p. 533. Y NUÑEZ CASTAÑO, E., "El delito de financiación ilegal de partidos políticos y la Unión Europea: un caso de corrupción al margen de la normativa europea", en GONZÁLEZ CANO, M. I. (Dir.): Cooperación Judicial Penal en la Unión Europea. Reflexiones sobre algunos aspectos de la investigación y el enjuiciamiento en el espacio europeo de justicia penal", Valencia, Tirant lo Blanch, 2015, p. 96.

25 JAVATO MARTÍN, A. M.: "El delito de...”, op. cit., p. 39.

26 PUENTE ABA, L. M.: El delito de financiación ilegal de partidos políticos, Valencia, Tirant lo Blanch, 2017, p. 135. 
cuatro años pudiendo alcanzar los seis años en casos de especial gravedad. De acuerdo con esta peculiar tipificación, “"participar en estructuras $u$ organizaciones, cualquiera que sea su naturaleza, cuya finalidad sea la financiación de partidos políticos al margen de la ley», será más grave que la propia financiación ilegal de partidos en su modalidad más grave"27.

Por otro lado, se ha advertido igualmente que las sanciones previstas en este precepto resultan más graves que las establecidas en los arts. 570 bis y ter CP; con la excepción de la dirección de la organización, cuyo marco penal es más amplio en el art. 570 bis CP que en el art. 304 ter CP. En este sentido, se ha propuesto que "tanto para evitar problemas de solapamiento como para establecer una cierta uniformidad en la respuesta punitiva a los fenómenos de organizaciones y grupos criminales, no debería haberse regulado de forma específica la dirección y pertenencia a una organización dedicada a la financiación de partidos políticos"28.

En último lugar, señalar que el art. 304 ter CP introduce un concepto hasta ahora inédito en el marco de las distintas estrategias de persecución de la delincuencia organizada cuando alude al término "estructuras". Un concepto que plantea como principal dificultad "fijar su concreto contenido y caracteres, lo que no es fácil por la exhaustividad con que se definen respectivamente las organizaciones y grupos criminales en los artículos 570 bis y siguientes, siendo estos últimos, los grupos criminales, con los que viene a coincidir las nuevas "estructuras" 29 .

\section{Incorporación de nuevos artículos al Título XIII bis}

Propuesta Grupo Parlamentario Mixto (Enmienda núm. 1):

Se propone la adición a la Ley Orgánica 10/1995, de 23 de noviembre, del Código Penal, de un artículo 304 quater con la siguiente redacción:

27 MAROTO CALATAYUD, M.: "Financiación ilegal...”, op. cit., pp. 764-765.

28 PUENTE ABA, L. M.: El delito de..., op. cit., p. 136.

29 SÁINZ-CANTERO CAPARRÓS, J. E.: "Los delitos de...”, op. cit., pp. 798-799. 
1. Cuando resulte acreditada la aplicación, por los partidos políticos, federaciones, coaliciones o agrupaciones de electores, de fondos o recursos de otro tipo procedentes de la financiación ilegal para sufragar gastos realizados con motivo u ocasión de una determinada campaña electoral, las condenas firmes impuestas por la comisión de alguno de los delitos de este título comprenderá también, en todo caso, la obligación de reintegrar a las Administraciones Públicas el importe total de las cantidades percibidas en concepto de subvenciones en la campaña electoral en la que se haya aplicado la indicada financiación ilegal, incluidas las recibidas en atención al número de votos y de puestos de representación institucional obtenidos.

2. En idéntico supuesto, los jueces y tribunales impondrán necesariamente como accesoria la pena prevista en la letra f) del apartado 7 del artículo 33.

Esta disposición no debe ser confundida con la figura del decomiso, también aplicable en caso de condena de un partido político, lo cual supondría devolver, por ejemplo, aquellos recursos obtenidos a través de una financiación ilícita ${ }^{30}$. Lo que se propone aquí es la pérdida del total de las subvenciones que el partido haya obtenido para una determinada campaña electoral cuando los fondos o recursos procedentes de la financiación ilegal se utilicen para sufragar gastos realizados con motivo $u$ ocasión de dicha campaña electoral. En nuestra opinión, para que ello fuere posible debiera producirse una modificación del art. 33.7 CP que actualmente no contempla dicha pena, sí la prohibición de obtener subvenciones, pero, no su pérdida. núm. 4):

Propuesta Grupo Parlamentario Socialista (Enmienda

\section{Artículo 304 quater}

El que cometiere en documento público, oficial o mercantil, alguna de las falsedades descritas en los tres primeros núme-

30 Vid. ampliamente, sobre esta cuestión, LEÓN ALAPONT, J.: "Decomiso y responsabilidad penal de los partidos políticos", Revista de Derecho y Proceso Penal, núm. 52, 2018, pp. 176-177. 
ros del apartado 1 del artículo 390, con la finalidad de falsear las cuentas anuales u otros documentos que deban reflejar la situación económica-financiera-patrimonial, de un partido politico, federación, coalición o agrupación de electores para negar, impedir u obstruir el control externo estos, será castigado, además de con las penas previstas para los concretos delitos cometidos, con las penas de prisión de dos a cuatro años y multa de doce a veinticuatro meses e inhabilitación especial para empleo o cargo público, profesión u oficio y derecho de sufragio pasivo de cuatro a diez años.

Cualquier otra omisión o falsedad deliberada de la situación económico- financiero-patrimonial de las entidades mencionadas para otras finalidades no previstas en el párrafo anterior serán castigadas con la pena inferior en grado.

\section{Artículo 304 quinquies}

Será castigado con las penas de prisión de seis meses a tres años y multa de seis a doce meses e inhabilitación especial para empleo o cargo público, profesión u oficio y derecho de sufragio pasivo de uno a dos años, el que con conocimiento de la comisión del delito previsto en el artículo 304 bis, 304 ter, 304 quater y sin haber participado en el mismo como autor o cómplice, interviniere con posterioridad en el mismo, ocultando, alterando o inutilizando el cuerpo, los efectos o instrumentos del delito para impedir su descubrimiento, o promoviendo alguna de estas conductas, para eludir la investigación de la autoridad o sus agentes.

En realidad, ambos preceptos no contemplan supuestos de financiación ilegal de partidos políticos. El primero de ellos refleja una modalidad de falsedad documental y, el segundo, un tipo de encubrimiento específico.

\section{Un debate desenfocado}

Más allá de los aspectos problemáticos que presenta una figura delictiva como la del art. 304 ter CP (de carácter más residual), el principal problema que sigue subsistiendo y que no se 
corrige en ninguna de las propuestas analizadas es la necesidad de dar un nuevo enfoque al art. 304 bis CP para que de verdad albergue supuestos de financiación ilegal de los partidos políticos. Por ello, a continuación, expondremos algunas de las pautas que, a nuestro juicio, el legislador debiera seguir para tratar de paliar dicha situación ${ }^{31}$.

En este sentido, dado el bien jurídico que estimamos queda protegido en el delito de financiación ilegal de los partidos políticos, a saber, la igualdad de oportunidades o competencia leal entre este tipo de formaciones (en materia de financiación) ${ }^{32}$, consideramos que el actual art. 304 bis CP alberga determinadas conductas delictivas que, a nuestro juicio, no atentan contra dicho interés, y viceversa, otras acciones potencialmente lesivas de éste no quedan comprendidas en tal precepto. De ahí que, coincidamos plenamente con PUENTE ABA cuando afirma que la actual regulación del delito de financiación ilegal de los partidos políticos no respeta ni el principio de subsidiariedad ni el de fragmentariedad ${ }^{33}$. En igual sentido, la penalidad descrita en el art. 304 bis CP, al menos para el caso de las personas jurídicas,

31 Pueden consultarse otras formulaciones como las desarrolladas por MAROTO CALATAYUD, M.: La financiación ilegal de los partidos políticos: un análisis político-criminal, Madrid, Marcial Pons, 2015, pp. 321-323. OLAIZOLA NOGALES, I.: La financiación ilegal de los partidos políticos: un foco de corrupción, Valencia, Tirant lo Blanch, 2014, pp. 197 y ss. Y NIETO MARTÍN, A.: "Financiación ilegal de partidos políticos (arts. 10-13)", en ARROYO ZAPATERO, L. y NIETO MARTÍN, A.: Fraude y corrupción en el Derecho penal económico europeo. Eurodelitos de corrupción y fraude, Cuenca, Ediciones de la Universidad de Castilla-La Mancha, 2006, pp. 127-136.

32 En este sentido, consideramos que la financiación ilegal de los partidos debiera concebirse (en este ámbito concreto) como un supuesto de "competencia desleal" entre este tipo de organizaciones, pues, la ventaja económica que pudiera obtenerse ilícitamente por la formación política correspondiente situaría a ésta en una mejor posición competitiva respecto del resto de partidos. Vid., con mayor nivel de detalle, LEÓN ALAPONT, J.: "El delito de financiación ilegal de los partidos políticos desde la perspectiva de la responsabilidad penal de éstos como personas jurídicas", InDret, núm. 4, 2018, pp. 9-10.

33 PUENTE ABA, L. M.: El delito de..., op. cit., p. 141. 
nos parece desproporcionada. De ahí, la propuesta de reforma que se expone a continuación.

\section{Planteamiento}

En primer lugar, a diferencia de lo que sucede en el vigente art. 304 bis CP, que sólo refiere a una clase de financiación muy concreta como son las donaciones, consideramos que el objeto material de dicho delito debiera extenderse a cualquier clase de financiación. De forma que, comprendiera la recepción de todo tipo de recursos (públicos o privados) de contenido económico-patrimonial o susceptibles de ser sometidos a tal valoración, como pudiera ser, a título de ejemplo, no sólo las donaciones de bienes muebles o inmuebles, sino también: subvenciones, asunción de gastos del partido (que implicarían para éste un ahorro de costes) ${ }^{34}$, concesión de préstamos, asunción o condonación de deudas, o la cesión de derechos (como los de usufructo o crédito), entre otros.

En segundo lugar, el listado de benefactores quedaría conformado por personas físicas, personas jurídicas y entes sin personalidad jurídica. Así, sería conveniente que desapareciese la mención expresa que efectúa el actual art. 304 bis CP a las donaciones de Gobiernos y organismos, entidades o empresas públicas extranjeras o de empresas relacionadas con los mismos, pues, ya quedarían comprendidos en la categoría de personas jurídicas (al no distinguirse entre nacionales y extranjeras).

En tercer lugar, la inclusión de la cláusula "directa o indirectamente" en determinados tipos contribuiría a conferir una protección lo más amplia posible al bien jurídico protegido, evitando así cualquier posible resquicio que condujera a la atipicidad de la conducta.

En cuarto lugar, la alusión que los arts. 304 bis 1 y 2 CP hacen al verbo "recibir" ha llevado a algunos autores a sostener que tanto la solicitud como la aceptación de aquellas donaciones

$34 \mathrm{El}$ art. 4.3 LOFPP se refiere a éstas como "operaciones asimiladas". 
consideradas delictivas resultarían atípicas ${ }^{35}$. Por ello, a pesar de que, a nuestro juicio, resultaría plausible concebir ambas modalidades como ejemplos de tentativa ${ }^{36}$, resultaría conveniente incluirlas expresamente en aquello tipos que por su naturaleza se presten a ello (como más adelante, se verá) para evitar cualquier margen interpretativo y, sobre todo, porque consideramos deben castigarse de forma autónoma. Ahora bien, ello no supone que estemos proponiendo elevar a categoría de delito meros actos preparatorios, como así han sido calificadas, por parte de alguna autora, la solicitud y aceptación ${ }^{37}$. Sino que los tipos de acción que consistieran en solicitar o aceptar cualquier clase de financiación quedarían configurados como tipos de peligro concreto. Por el contrario, sí merecería la consideración de acto preparatorio, a título de ejemplo, el proponerse solicitar una donación a un empresario a cambio de adjudicarle directamente (sin licitación alguna) un determinado contrato público. Sin embargo, no se plantea en esta modificación del art. 304 bis CP la necesidad de castigar la realización de actos preparatorios como el que aquí se ha traído a colación.

Por último, señalar que, aunque en la propuesta que a continuación se detalla nos centremos sólo en describir las conductas que podrían ocasionar la responsabilidad penal del partido destinatario de la financiación ilegal y de las personas físicas que contribuyan a tal fin, ello no significa, naturalmente, que nos hayamos olvidado de la otra parte del binomio, esto es, de quienes soliciten, acepten o lleguen a financiar a un partido de

35 Así, por ejemplo, NUÑEZ CASTAÑO, E.: "La cuestionable regulación penal de los delitos de financiación ilegal de partidos políticos”, Revista Penal, núm. 39, 2017, p. 140. Y MUÑOZ CUESTA, F. J.: "Delitos de financiación ilegal de partidos políticos”, Revista Aranzadi Doctrinal, núm. 5, 2015, p. 14.

36 En el caso de "solicitar" se trataría de una tentativa inacabada. Y, en el de "aceptar", estaríamos ante una tentativa acabada.

37 Cfr. SIERRA LÓPEZ, M. V.: "El delito de financiación ilegal de partidos políticos: ¿mayor eficacia en la lucha contra la corrupción?”, en GÓMEZ RIVERO, M.C. y BARRERO ORTEGA, A. (Dirs.): Regeneración democrática y estrategias penales en la lucha contra la corrupción, Valencia, Tirant lo Blanch, 2017, p. 806. 
la forma prevista en los apartados primero a quinto (vid. infra 2), lo cual conllevaría el correspondiente reproche penal ${ }^{38}$. Y, tampoco, que sólo sea delito (en los términos aquí propuestos) la financiación ilegal de los partidos políticos, sino también la que afecte a las federaciones de éstos, coaliciones electorales o agrupaciones de electores. Si bien, son cuestiones que no podemos atender por exceder del objeto de este trabajo.

\section{Las conductas delictivas}

Se proponen los siguientes tipos penales ${ }^{39}$ :

1) Solicitar, aceptar, o recibir, directa o indirectamente, cualquier tipo de financiación de carácter anónimo.

Los tipos de acción aquí formulados se configurarían todos ellos como tipos de peligro concreto, por cuanto el anonimato impide identificar no sólo quién es el benefactor, sino que, además, dificulta o imposibilita averiguar la procedencia (lícita o ilícita) de dicha contribución, así como el destino o finalidad de la misma, y ello se traduce en que existe la probabilidad de que el bien jurídico protegido resulte dañado, pues, tales conductas generarían una situación objetiva de riesgo específico para aquél.

38 Nos referimos, básicamente, a personas físicas, fundaciones, empresas o instituciones que financien ilegalmente a un partido político. También, y aun cuando resulta difícil de imaginar que una formación política se dedique a financiar de manera ilegal a otro partido, federación, coalición o agrupación de electores, nada obsta, en realidad, para que ello suceda. Con todo, consideramos que las penas que cabría imponer en estos casos debieran ser las mismas que se detallan en esta propuesta, a imagen y semejanza de lo que ocurre con el actual art. 304 bis 4 CP cuando alude a "Las mismas penas se impondrán, en sus respectivos casos, a quien entregare donaciones o aportaciones destinadas a un partido político, federación, coalición o agrupación de electores, por sí o por persona interpuesta, en alguno de los supuestos de los números anteriores".

39 Naturalmente, la propuesta que aquí planteamos obligaría a reformar la LOFPP y la LOREG, por cuanto algunos de los supuestos que mencionamos a continuación son perfectamente legales con la actual regulación. 
Ejemplo: un determinado partido inicia una campaña de crowdfunding en la que los donantes no tienen la obligación de identificarse. En consecuencia, el partido puede recibir numerosas pequeñas aportaciones tanto de personas bienintencionadas y comprometidas con los ideales de éste como provenientes de una organización criminal (lo cual no sería detectable). De suceder esto último, el partido se vería en una posición competitiva ventajosa respecto del resto de formaciones políticas que deciden no recurrir a este tipo de financiación totalmente opaca.

2) Solicitar, aceptar, o recibir, directa o indirectamente, cualquier tipo de financiación de carácter finalista o revocable de personas físicas, personas jurídicas o entes sin personalidad jurídica.

Entendiéndose por financiación de carácter finalista aquella que se dirige a lograr la actuación del partido en un determinado sentido (lícito o no) con independencia de que ésta se produzca antes o después de la solicitud, aceptación, o recepción de la financiación. Por financiación de carácter revocable se entenderá aquella susceptible de ser retirada en caso de no cumplirse la condición a la que quede sujeta.

Las conductas relativas a solicitar o aceptar este tipo de financiación deben concebirse como tipos de peligro concreto, mientras que la de recibir aquélla se erige en un tipo de lesión. En cualquier caso, la probabilidad de afectación del bien jurídico o su efectiva lesión derivaría de la siguiente circunstancia: aquellos partidos que no se prestan a vender su "voluntad" o no están dispuestos a incurrir en ilegalidades (que es lo que cabría esperar de ellos), estarían en condiciones de inferioridad respecto de aquellos que sí opten por esa otra senda.

Ejemplos: a) un Gobierno extranjero realiza una donación de 10 millones de dólares al partido que sustenta al Ejecutivo para que se apruebe la instalación de una base militar en territorio español; b) una entidad de crédito condona toda la deuda que tenía contraída un determinado partido con aquélla a cambio de que interceda para que se le conceda el indulto al presidente de dicho banco (que ha sido condenado por blanqueo de capitales); c) un empresario (persona física) promete a un partido pagarle 
todos los gastos de una concreta campaña electoral si se le adjudica el contrato de gestión de aguas residuales de un importante municipio (el cual debiera licitarse).

No obstante, si bien hemos sostenido que podría castigarse a un partido por solicitar, aceptar, o recibir financiación dirigida a conseguir una concreta actuación por su parte (aun cuando fuera para un fin lícito), determinadas conductas en este ámbito podrían considerarse irrelevantes por carecer de la más mínima carga ofensiva.

Ejemplo: un empresario decide que el partido político para el que suele trabajar no le efectúe el pago de los últimos servicios contratados a cambio de que éste siga contando con él en futuras ocasiones.

3) Solicitar, aceptar, o recibir, directa o indirectamente, cualquier tipo de financiación privada de origen ilícito de personas fisicas, personas jurídicas o entes sin personalidad jurídica.

Una vez más, tanto la solicitud como la aceptación de dicha financiación constituirían tipos de peligro concreto, y la recepción, por su parte, un tipo de lesión. El recurso a este tipo de financiación atentaría contra la competencia leal que se presupone debiera existir o exigírsele a estas organizaciones, competencia leal que consistiría en que los partidos se pudieran financiar sin límites cuantitativos, pero sí cualitativos, esto es, que se financiasen única y exclusivamente con recursos totalmente lícitos.

Ejemplos de financiación de origen ilícita: cualquiera procedente de un delito como pudieran ser los de malversación de caudales públicos, cohecho, apropiación indebida, estafa, robo, tráfico de drogas, prostitución, etc.

Repárese, por otro lado, en el hecho de que no hayamos aludido a que dicho origen ilícito deba ser conocido. De darse esto último el delito de financiación ilegal podría entrar en concurso (ideal) con el de blanqueo de capitales. 
4) Solicitar, aceptar, o recibir, directa o indirectamente, cualquier tipo de financiación pública de forma ilegal o fraudulenta.

Aquí también, los tipos de acción consistentes en solicitar o aceptar constituirían tipos de peligro concreto, y la recepción quedaría configurada como un tipo de lesión. La finalidad pretendida con las conductas descritas sería la de evitar que el partido que recurriese a este tipo de artes consiguiera una ventaja competitiva (de carácter económico) que le situara en una mejor posición con respecto del resto de formaciones políticas.

Ejemplos: a) recibir de forma fraudulenta una subvención para gastos electorales; b) solicitar que se le asigne al partido una subvención para gastos ordinarios de mayor cuantía a la que le correspondería por ley; c) aceptar (en el sentido de acordar o aprobar) que se le conceda al partido una subvención de forma camuflada, por ejemplo, a través de una de sus fundaciones, con el objetivo de que efectivamente revierta finalmente en el partido; d) recibir mayor asignación de espacios en lugares públicos y medios de comunicación pública con ocasión de los comicios electorales; e) acceder a una línea de financiación por parte del Instituto de Crédito Oficial (reservada a empresas).

5) Solicitar, aceptar, o recibir, directa o indirectamente, cualquier tipo de financiación de los grupos parlamentarios de las Cámaras de las Cortes Generales, de las Asambleas Legislativas de las Comunidades Autónomas, de las Juntas Generales de los Territorios Históricos vascos y de los grupos de representantes en los órganos de las Administraciones Locales.

Actualmente, la LOFPP (art. 2.1) permite el trasvase de fondos de estos grupos a los partidos, y no impide que asuman los gastos de éstos. Por tanto, se trata de una vía de financiación legal ${ }^{40}$. Sin embargo, a nuestro juicio, las conductas arriba descritas atentarían o pondrían en riesgo la igualdad de oportunidades entre partidos (en los términos ya expuestos) porque

40 LEÓN ALAPONT, J.: “¿Responsabilidad criminal de los grupos parlamentarios?", Revista General de Derecho Penal, núm. 28, 2017, pp. 19-20. 
aquellas organizaciones políticas que se beneficiaran o pudieran beneficiarse con tales fondos, obtendrían, o podrían obtener, mayores recursos para su financiación que aquellos que no decidieran recurrir a esta vía porque consideraran que con ello se estaría alejando, a tales grupos, de los fines para los que fueron creados (y esto último, a nuestro entender, debería ser respetado $)^{41}$.

6) Superar en más de un uno por ciento los límites de gastos electorales previstos en la Ley Orgánica 5/1985, de 19 de junio, del Régimen Electoral General o, en su caso, en las respectivas leyes electorales autonómicas.

Esta conducta que en la actualidad es constitutiva de infracción administrativa ${ }^{42}$, consideramos debiera ser delictiva puesto que atenta contra la igualdad de oportunidades entre partidos políticos en materia de financiación. En esta ocasión, se trata de una igualdad impuesta por la legislación electoral que establece para todas las formaciones políticas límites a sus gastos electorales. De forma que, aquellos partidos que infringieran dichas restricciones no estarían concurriendo en condiciones de igualdad a los comicios. Tratándose, efectivamente, de un tipo de lesión.

A este respecto, cabe señalar que la lesión del bien jurídico protegido en el delito de financiación ilegal de los partidos no sólo puede producirse cuando lo que se obtiene son recursos en forma de ingresos o ahorro de costes, sino también, como en el presente caso, cuando los propios recursos disponibles por el partido se utilizan superando los límites establecidos por la ley. De ahí la importancia de referirnos, a este delito, como de financiación ilegal de los partidos políticos; y no de financiación

41 Como ha resaltado el Tribunal Constitucional, dos son, principalmente, los tipos de funciones que desempeñan estos entes: por un lado, las relativas a la organización y funcionamiento de la Cámara y, por otro, las estrictamente parlamentarias. Así, SSTC 64/2002, de 11 de marzo; 141/2007, de 18 de junio; 10/2013, de 28 de enero; 107/2016, de 7 de junio; 108/2016, de 7 de junio; y 109/2016, de 7 de junio.

42 Así lo establece el art. 17 LOFPP, y lo mismo sucede con las respectivas leyes electorales autonómicas. 
ilegal de partidos políticos (pues esta última terminología induce a pensar que únicamente quedan abarcados los supuestos de financiación activa y externa).

7) Distraer fondos del partido destinados a gastos ordinarios para fines electorales, o viceversa.

Entendiéndose por gastos ordinarios todos aquellos en los que pueda incurrir una formación política a excepción de los electorales.

Téngase en cuenta, en este sentido, que el propio art. 125.1 LOREG establece la obligación de que todos los fondos destinados a sufragar los gastos electorales, cualquiera que sea su procedencia, deben ingresarse en cuentas abiertas a tales efectos y todos los gastos deben pagarse con cargo a las mismas. En cambio, los partidos que no respetasen tal regla se situarían (en términos económicos) en una posición ventajosa respecto de aquellos que sí cumpliesen con la misma. Así, estaríamos ante una forma de "autofinanciación" ilegal y, naturalmente, ante un tipo de lesión.

Ejemplo: con parte de los fondos electorales se abonan los salarios de los trabajadores del partido.

Por otro lado, deberá tenerse en cuenta que en determinadas situaciones podrían plantearse concursos de delitos. Así sucedería, por ejemplo, de abonarse (con parte de las subvenciones obtenidas para gastos de funcionamiento) un acto de campaña. Conducta que no sólo sería constitutiva de financiación ilegal sino también de malversación de subvenciones, pues se lesionarían dos bienes jurídicos distintos.

8) Traspasar fondos del partido destinados a gastos ordinarios a cuentas para fines electorales, o viceversa.

El motivo por el cual consideramos debiera incriminarse dicha conducta coincide con la explicación dada en el apartado anterior. Si bien la diferencia aquí estriba en que no constituiría un tipo de lesión, sino de peligro concreto. 
Ejemplo: para no incurrir en delito, al distraer fondos destinados a gastos electorales para pagar una reforma de la sede del partido, éste se limita a realizar un traspaso entre cuentas. De forma que, aparentemente, la reforma de la sede fuera sufragada con fondos para gastos ordinarios.

\section{La delimitación entre las conductas delictivas y las infracciones administrativas}

En nuestra opinión, sólo las conductas anteriormente enumeradas debieran ser las que integrasen el delito de financiación ilegal del art. 304 bis CP, pues, como ya se advirtió, sólo los tipos aquí descritos otorgarían una adecuada protección al bien jurídico tutelado en este delito. Así las cosas, entendemos que no merecerían la consideración de delictivos una serie de supuestos, como los que a continuación pasamos a mencionar, por tratarse de conductas que no entrañarían desvalor alguno:

a) Una empresa española dona 500.000 euros a un partido porque lleva en su programa electoral una bajada considerable del impuesto de sociedades ${ }^{43}$.

b) Una empresa brasileña dona 1 millón de dólares a un partido que apoya un plan de beneficios fiscales para las inversiones extranjeras.

c) El Gobierno de Corea del Norte financia con $10 \mathrm{mi}-$ llones de dólares a un partido que defiende para España su mismo modelo de Estado.

d) Un director de cine dona 100.000 euros a un partido que ha impulsado la aprobación de un mecanismo de financiación para la producción de películas en gallego.

43 Así, por ejemplo, la Supreme Court of the United States permite a las empresas hacer aportaciones ilimitadamente a los partidos bajo el principal argumento de que lo contrario supondría una violación del derecho a la libertad de expresión. Vid., sobre este particular, RODRÍGUEZ-AGUILERA DE PRAT, C.: Manual de partidos políticos, Barcelona, Huygens Editorial, 2017 , p. 70. 
e) Una entidad de crédito condona toda la deuda de un partido que se opone a la creación de un nuevo impuesto específico para los bancos ${ }^{44}$.

f) Un empresario (persona física) con contrato vigente con la Administración Pública asume los gastos de la campaña electoral de un partido (valorados en 2 millones de euros) porque resulta que su hijo va incluido en las listas electorales.

g) Una de las fundaciones vinculadas a un partido asume el pago de las nóminas de los trabajadores de aquél ante los problemas puntuales de liquidez que presenta la formación política.

Sin ánimo de ser exhaustivos, hemos pretendido transmitir la idea de que, incriminar tales tipos de financiación con arreglo a meras presunciones sobre el origen corrupto o finalidad ilícita de cualquier clase de financiación hecha a una organización política sería tanto como configurar no ya un delito de peligro abstracto sino de sospecha. Por el contrario, si lo que se tienen son indicios racionales de que ello es así, será entonces cuando deban depurarse las respectivas responsabilidades penales. En el supuesto concreto de las fundaciones, se critica que el destino de parte de su patrimonio a los partidos supone un claro incumplimiento de los fines de aquéllas ${ }^{45}$. Sin embargo, precisamente, la razón de ser de éstas es servir de apoyo (también económico) a los partidos a las que quedan vinculadas ${ }^{46}$.

44 Especial reticencia ha generado esta cuestión en la doctrina, mostrándose a favor de su incriminación. Vid., por todos, JAVATO MARTÍN, A. M.: "Artículo 304 bis", en GÓMEZ TOMILLO, M. (Dir.): Comentarios prácticos al Código Penal. Tomo III, Cizur Menor, Thomson Reuters-Aranzadi, 2015, p. 720 .

45 REBOLLO VARGAS, R.: "La polémica en el delito de financiación de partidos políticos: las puertas continúan abiertas”, Estudios Penales y Criminológicos, núm. 38 (extr.), 2018, p. 93.

46 La propia Ley 50/2002, de 26 de diciembre, de Fundaciones, en su art. 3.3 dispone que "en ningún caso podrán constituirse fundaciones con la finalidad principal de destinar sus prestaciones al fundador o a los patronos, a sus cónyuges o personas ligadas con análoga relación de afectividad, o a sus parientes hasta el cuarto grado inclusive, así como a personas juridicas singularizadas que no persigan fines de interés general”. En cambio, 
Ahora bien, así como hemos defendido que no deberían ser delictivas aquellas conductas a las cuales nos acabamos de referir, consideramos que sería ineludible la imposición (a los partidos políticos) de obligaciones en materia de trasparencia respecto de esta clase de contribuciones (en términos de publicidad) ${ }^{47}$, pues, ello permitiría el control de la ciudadanía sobre éstas ${ }^{48}$. Lo cual, naturalmente, debería ir acompañado de las respectivas sanciones por el incumplimiento de tales obligaciones. Como gráficamente describe DOPICO GÓMEZ-ALLER, "la financiación privada de los partidos es absolutamente opaca para todos los habitantes del planeta, salvo para las escasas personas que trabajan en la Unidad de fiscalización de Partidos Políticos del Tribunal de Cuentas"49.

A pesar de lo aquí sostenido, en relación a este tipo de conductas, el legislador podría decidir sancionarlas administrativamente o no (cuestión ésta que no va a ser objeto de valoración por nuestra parte en este trabajo). Empero, de hacerlo, esto es, de sancionar por vía administrativa aquellas conductas que estimase conveniente, tal determinación respondería a otros fines seguramente igual de legítimos que el que justifica en este ámbito la intervención penal, pero, a su vez, totalmente distintos a éste. Así, por ejemplo, podría estimarse que la prohibición

resulta evidente que las organizaciones políticas sí cumplen con tales fines generales. Por eso, no creemos que pueda afirmarse que cuando una fundación de un partido financie a éste se esté apartando o desviando de sus fines.

47 OLAIZOLA NOGALES, I.: "El delito de financiación ilegal de partidos políticos en la reforma del CP”, Diario La Ley, núm. 8516, 2015, p. 5.

48 NAVARRO CARDOSO alude al "control social" que permite la transparencia como una de las principales ventajas de ésta. Cfr. NAVARRO CARDOSO, F.: "El derecho de acceso a la información pública como instrumento de transparencia en la lucha contra la corrupción y su tutela penal", en MATALLÍN EVANGELIO (Dir.), Compliance y prevención de delitos de corrupción, Valencia, Tirant lo Blanch, 2018, p. 271.

49 DOPICO GÓMEZ-ALLER, J.: "Aproximación a las necesidades de reforma legal en relación con la respuesta penal a la corrupción política”, en GIL NOBAJAS, M. S., et al.: Estudios sobre el Anteproyecto de Ley Orgánica del Poder Judicial y sobre la corrupción en el ámbito público, Bilbao, $\mathrm{Pu}-$ blicaciones de la Universidad de Deusto, 2015, p. 274. 
de efectuar o recibir cualquier tipo de financiación de personas físicas o jurídicas o entes sin personalidad jurídica (superados ciertos límites) respondería al deseo del legislador de restringir la financiación de carácter privado de los partidos para que hubiera cierto equilibrio con la de origen público; o prohibirse cualquier tipo de financiación de personas físicas o jurídicas o entes sin personalidad jurídica extranjeros porque el legislador ha considerado que los partidos sólo pueden recibir financiación nacional. Ahora bien, la distinción entre infracciones administrativas y supuestos delictivos no debe reducirse a una cuestión cuantitativa (de umbrales), sino cualitativa (del tipo de financiación que debiera considerarse delictiva). Los límites (en uno y otro ámbito sancionador) pueden y deben ser útiles para graduar la gravedad de los hechos y por ende de la consecuencia jurídica, pero, no para deslindar la infracción administrativa de la penal.

No obstante, el conservar la vía administrativa para sancionar determinados hechos implicaría, en primer lugar, una importante reforma del Tribunal de Cuentas (cuando se trate de infracciones de la LOFPP) que dotara a éste de una mínima potestad investigadora que en la actualidad no tiene $e^{50}$, de forma que su cometido no quedara limitado a un control meramente formal de la legalidad y la regularidad contable de las actuaciones de los partidos $^{51}$; y, por otro lado, que se precisara cómo proceder a la ejecución de las sanciones acordadas ${ }^{52}$. Y, en segundo lugar,

50 RODRÍGUEZ PUERTA, M. J.: "El control externo de la actividad económico financiera de los partidos políticos en España: cuestiones a debatir", Revista General de Derecho Penal, núm. 28, 2017, p. 58.

51 GARCÍA-PANDO MOSQUERA, J. J.: "Las cuentas de la democracia", en NIETO MARTÍN, D. y MAROTO CALATAYUD, M. (Dirs.): Public compliance. Prevención de la corrupción en administraciones públicas y partidos políticos, Cuenca, Ediciones de la Universidad de Castilla-La Mancha, 2014, p. 151.

52 Lo cual no está previsto en la actual regulación, como señala DELGADO DEL RINCÓN, L. E.: "Hacia un modelo idóneo de control externo de la actividad económico-financiera de los partidos políticos por el Tribunal de Cuentas", en MATIA PORTILLA, F. J. (Dir.): Problemas actuales sobre el control de los partidos políticos, Valencia, Tirant lo Blanch, 2016, p. 447. 
que la capacidad sancionadora de las diversas Juntas Electorales (en el ámbito de la LOREG) se extendiera también sobre los partidos políticos, lo cual no sucede en la actualidad (ex art. 153 LOREG).

\section{Penas a imponer}

La única pena que se prevé con carácter obligatorio para el partido político en el actual art. 304 bis CP es la de multa ${ }^{53}$. Siendo ésta del triplo al quíntuplo del valor de la donación recibida cuando se trate de: donaciones anónimas, finalistas o revocables; donaciones procedentes de una misma persona física superiores a 50.000 euros anuales; donaciones procedentes de personas jurídicas y de entes sin personalidad jurídica; $y$, donaciones en especie de bienes inmuebles (superiores a 50.000 euros) en las que no se especifique, además de la identificación del donante, el documento en que conste la entrega del bien y no se haga mención al carácter irrevocable de la misma (art. 304 bis $1 \mathrm{CP}$ ). Del triplo al quíntuplo de su valor cuando se trate de donaciones anónimas, finalistas o revocables y de personas jurídicas o entes sin personalidad jurídica superiores a 500.000 euros (art. 304 bis 2 CP). Y del triplo al quíntuplo del exceso de aquellas donaciones de Gobiernos y organismos, entidades o empresas públicas extranjeras o de empresas relacionadas directa o indirectamente con los mismos que superen los 100.000 euros; $\mathrm{y}$ de aquellas donaciones de personas físicas que superen en más de 500.000 euros el límite de los 50.000 euros anuales (art. 304 bis $2 \mathrm{CP})^{54}$.

53 Para el caso de las personas físicas, el art. 304 bis CP sólo establece pena de prisión de seis meses a cuatro años para los supuestos del apartado segundo. Y, siempre y en todo caso, la pena de multa del triplo al quíntuplo.

54 Por su parte, el art. 304 bis 3 CP contempla que, si los hechos descritos en el apartado segundo de dicho precepto resultaran de "especial gravedad", se impondrá la pena en su mitad superior, pudiéndose llegar hasta la superior en grado. A pesar de la imprecisión de dicha expresión, la doctrina ha convenido en que para que unos hechos resulten de especial gravedad deberán valorarse, entre otros, aspectos tales como la relevancia económica de la conducta delictiva, las condiciones en que tiene lugar la donación, las 
Como puede observarse, el importe de la multa a imponer sobre el partido es el mismo con independencia del tipo de donación de que se trate cuando, precisamente, las conductas recogidas en el art. 304 bis $2 \mathrm{CP}$ son consideradas más graves y por eso llevan aparejada pena de prisión para las personas físicas (lo cual no sucede en el art. 304 bis 1 CP). Pero, en cambio, este plus de desvalor no se refleja en una multa de mayor cuantía para el partido en estos supuestos, lo cual resulta incomprensible. Esta situación, consideramos debiera ser corregida en una futura reforma del art. 304 bis CP. De forma que, la propuesta de lege ferenda que aquí se ha planteado respecto del tipo penal tendría que ir acompañada de la correspondiente graduación de la pena de multa (que pasamos a formular acto seguido) para así respetar el principio de proporcionalidad:

a) en el supuesto de solicitar o aceptar, directa o indirectamente, cualquier tipo de financiación de carácter anónimo, la pena de multa sería de dos a seis meses.

b) en los supuestos de solicitud o aceptación, directa o indirecta, de cualquier tipo de financiación de carácter finalista o revocable, de origen ilícito, pública o de los grupos parlamentarios y de representantes (en los términos ya expuestos), la pena de multa sería de seis meses a un año $0^{55}$.

c) en el supuesto de recepción, directa o indirecta, de financiación de carácter anónimo, la pena de multa sería del tanto al triplo del valor de ésta.

circunstancias inherentes al autor del delito o la especial finalidad perseguida por el donante. Vid. MORALES HERNÁNDEZ, M. Á.: "Los delitos de financiación ilegal de los partidos políticos", en MARÍN DE ESPINOSA CEBAllos, E. M. (Dir.): Lecciones de Derecho Penal. Parte Especial, Valencia, Tirant lo Blanch, 2018, pp. 263-264.

55 Como puede apreciarse, existe una diferencia penológica entre los hechos de los apartados a) y b); así como entre las conductas de los apartados c) y d). La explicación es la siguiente: aunque el castigo de la financiación anónima obedece a que no se puede conocer el origen de la misma, esta circunstancia justifica una distinta penalidad en relación con los otros supuestos, pues, no hay que olvidar que la financiación anónima puede ser perfectamente lícita, lo único que ocurre es que no queda identificado quien es el benefactor. 
En este caso, consideramos que para la persona física responsable de los hechos debería establecerse, junto con la pena de multa anteriormente descrita, una pena de prisión de 6 meses a 2 años.

d) en los supuestos de recepción, directa o indirecta, de cualquier tipo de financiación de carácter finalista o revocable, de origen ilícito, pública o de los grupos parlamentarios y de representantes (en los términos ya expuestos), la pena de multa sería del triplo al quíntuplo del valor de ésta.

En este caso, consideramos que para la persona física responsable de los hechos debería establecerse, junto con la pena de multa anteriormente descrita, una pena de prisión de uno a cuatro años.

e) en caso de superar en más de un uno por ciento los límites de gastos electorales, la pena de multa sería la siguiente:

- del tanto al duplo del exceso si se han superado los límites de gastos electorales en más de un uno y hasta un tres por ciento.

- del duplo al triplo del exceso si se han superado los límites de gastos electorales en más de un tres y en menos de un diez por ciento.

- del triplo al quíntuplo del exceso si se han superado los límites de gastos electorales en un diez por ciento o más.

f) en el supuesto de distraer fondos del partido destinados a gastos ordinarios para fines electorales, o viceversa, la pena de multa sería del triplo al quíntuplo del valor de éstos.

g) en el supuesto de traspasar fondos del partido destinados a gastos ordinarios a cuentas para fines electorales, o viceversa, la pena de multa sería del tanto al triplo del valor de éstos.

Para concluir este apartado, simplemente queremos dejar anotada la posibilidad de que el legislador introdujese para los supuestos arriba mencionados -a excepción de lo ya previsto en el apartado e)- una gradación de las penas en función de ciertos límites cuantitativos. Ello dotaría de mayor coherencia al sistema de penas propugnado para un nuevo art. 304 bis CP. 


\section{A modo de conclusión}

La inclusión en nuestro Código Penal de un Título XIII bis dedicado a los delitos de financiación ilegal de partidos fue, en nuestra opinión, una decisión acertada. Máxime cuando desde 2010 las personas jurídicas, y desde 2012 los partidos políticos, pueden ser penalmente responsables. Ahora bien, dicho lo cual, y por los argumentos esgrimidos en este trabajo, el legislador podría haberse ahorrado dicho esfuerzo, pues, en el art. 304 bis CP se tipifican conductas que, a nuestro modo de ver, no deberían ser delictivas y, en cambio, otras que sí debieran serlo no se incriminan. Por otro lado, en cuanto al art. 304 ter $\mathrm{CP}$, la confusión a que se presta invita a pensar que la voluntas legislatoris y la redacción dada finalmente al precepto no son coincidentes. Sorprendiendo, además, que no se prevea también la sanción de las personas jurídicas responsables de los hechos descritos en dicho artículo.

En este sentido, es de agradecer la preocupación mostrada por algunos grupos parlamentarios respecto de la conveniencia de reformar los arts. 304 bis CP y 304 ter CP. Aun así, como se ha expuesto en este trabajo, y salvo aquellos aspectos en los que hemos mostrado nuestra conformidad con lo propuesto (principalmente en relación con el art. 304 ter CP), cabe advertir que las modificaciones sugeridas por los distintos grupos parlamentarios en la XII Legislatura (ya caducada) no van, a nuestro entender, en la buena dirección. Por tanto, esperemos que, de retomarse dicha voluntad reformista en relación a estos preceptos, las propuestas aquí traídas a colación sean reconsideradas.

En definitiva, en el art. 304 bis CP no se confiere una adecuada protección al bien jurídico tutelado en esta figura delictiva, a saber, la igualdad de oportunidades (o competencia leal) entre formaciones políticas en materia de financiación. $\mathrm{O}$, dicho de otro modo, la reforma del delito de financiación ilegal de los partidos políticos debería ser atendida cuanto antes si lo que de verdad se quiere castigar en él es, valga la redundancia, la financiación ilegal. Y respecto del art. 304 ter CP, se debería in- 
corporar que las estructuras $\mathrm{u}$ organizaciones que financien a un partido o federación de partidos se encuentren incardinadas de manera estable y permanente, dependan, mantengan un vínculo de conexión o hayan sido creadas por éstos, debiéndose otorgar también responsabilidad penal en estos supuestos a los partidos $\mathrm{y}$, en su caso, a cualquier tipo de persona jurídica (art. 31 bis CP) o ente sin personalidad jurídica (art. 129 CP).

\section{Bibliografía}

BASSO, G. J.: "Delitos de financiación ilegal de los partidos políticos", en MOLINA FERNÁNDEZ, F. (Coord.): Penal 2017, Madrid, Francis Lefebvre, 2016, pp. 1399-1408.

BUSTOS RUBIO, M.: "El nuevo delito de financiación ilegal de partidos políticos", Revista Penal, núm. 37, 2016, pp. 61-79.

DELGADO DEL RINCÓN, L. E.: "Hacia un modelo idóneo de control externo de la actividad económico-financiera de los partidos políticos por el Tribunal de Cuentas", en MATIA PORTILLA, F. J. (Dir.): Problemas actuales sobre el control de los partidos políticos, Valencia, Tirant lo Blanch, 2016, pp. 423-470.

DOPICO GÓMEZ-ALLER, J.: “Aproximación a las necesidades de reforma legal en relación con la respuesta penal a la corrupción política", en GIL NOBAJAS, M. S., et al.: Estudios sobre el Anteproyecto de Ley Orgánica del Poder Judicial y sobre la corrupción en el ámbito público, Bilbao, Publicaciones de la Universidad de Deusto, 2015, pp. 257-284.

GARCÍA-PANDO MOSQUERA, J. J.: "Las cuentas de la democracia”, en NIETO MARTÍN, D. y MAROTO CALATAYUD, M. (Dirs.): Public compliance. Prevención de la corrupción en administraciones públicas y partidos políticos, Cuenca, Ediciones de la Universidad de Castilla-La Mancha, 2014, pp. 131-154.

GONZÁLEZ GUGEL, J.: "Financiación ilegal de partidos políticos", en AYALA GÓMEZ, I. y ORTIZ DE URBINA 
GIMENO, I. (Coords.): Penal económico y de la empresa 2016-2017, Madrid, Francis Lefebvre, 2016, pp. 725-727. HAVA GARCÍA, E.: "Financiación ilegal de partidos políticos", en TERRADILLOS BASOCO, J. M. (Coord.): Lecciones y materiales para el estudio del Derecho penal. Tomo III. Derecho penal parte especial. Volumen I, Madrid, Iustel, 2016, pp. 455-465.

JAVATO MARTÍN, A. M.: "El delito de financiación ilegal de los partidos políticos (arts. 304 bis y 304 ter CP). Aspectos dogmáticos, político-criminales y de derecho comparado, Revista Electrónica de Ciencia Penal y Criminología, núm. 19-26, 2017, pp. 1-41.

— "Artículo 304 bis", en GÓMEZ TOMILLO, M. (Dir.): Comentarios prácticos al Código Penal. Tomo III, Cizur Menor, Thomson Reuters-Aranzadi, 2015, pp. 717-725.

LEÓN ALAPONT, J.: La responsabilidad penal de los partidos políticos, Valencia, Tirant lo Blanch, 2019.

_ "Partidos políticos y responsabilidad penal: una reflexión en torno al sistema de penas, Teoría y Derecho, núm. 25, 2019, pp. 206-237.

— "Decomiso y responsabilidad penal de los partidos políticos", Revista de Derecho y Proceso Penal, núm. 52, 2018, pp. 171-202.

- "El delito de financiación ilegal de los partidos políticos desde la perspectiva de la responsabilidad penal de éstos como personas jurídicas", InDret, núm. 4, 2018, pp. 1-36.

— "Partidos políticos y responsabilidad penal de las personas jurídicas: consideraciones en torno a su régimen jurídico y los compliances programs", en MATALLÍN EVANGELIO, Á. (Dir.), Compliance y prevención de delitos de corrupción, Valencia, Tirant lo Blanch, 2018, pp. 153-191.

— “¿Responsabilidad criminal de los grupos parlamentarios?”, Revista General de Derecho Penal, núm. 28, 2017, pp. 1-40.

- "La responsabilidad penal de los partidos políticos en España: ¿disfuncionalidad normativa?", Revista General de Derecho Penal, núm. 27, 2017, pp. 1-42. 
MAROTO CALATAYUD, M.: La financiación ilegal de los partidos políticos: un análisis político-criminal, Madrid, Marcial Pons, 2015.

— "Financiación ilegal de partidos políticos", en QUINTERO OLIVARES, G. (Dir.): Comentario a la reforma penal de 2015, Cizur Menor, Thomson Reuters-Aranzadi, 2015, pp. 755-768.

- “Autorregulación y legitimidad corporativa: democracia interna y control social en partidos políticos y empresas", en ARROYO JIMÉNEZ, L y NIETO MARTÍN, A. (Dirs.): Autorregulación y sanciones, Cizur Menor, Thomson Reuters-Aranzadi, 2015, pp. 369-418.

MORALES HERNÁNDEZ, M. Á.: "Los delitos de financiación ilegal de los partidos políticos", en MARÍN DE ESPINOSA CEBALLOS, E. M. (Dir.): Lecciones de Derecho Penal. Parte Especial, Valencia, Tirant lo Blanch, 2018, pp. 255-267.

MUÑOZ CONDE, F.: Derecho penal. Parte especial, Valencia, Tirant lo Blanch, 2017.

MUÑOZ CUESTA, F. J.: "Delitos de financiación ilegal de partidos políticos", Revista Aranzadi Doctrinal, núm. 5, 2015, pp. 11-21.

NAVARRO CARDOSO, F.: "El derecho de acceso a la información pública como instrumento de transparencia en la lucha contra la corrupción y su tutela penal”, en MATALLÍN EVANGELIO (Dir.), Compliance y prevención de delitos de corrupción, Valencia, Tirant lo Blanch, 2018, pp. 271-288.

NIETO MARTÍN, A.: "Financiación ilegal de partidos políticos (arts. 10-13)", en ARROYO ZAPATERO, L. y NIETO MARTÍN, A.: Fraude y corrupción en el Derecho penal económico europeo. Eurodelitos de corrupción y fraude, Cuenca, Ediciones de la Universidad de Castilla-La Mancha, 2006, pp. 117-138.

NUÑEZ CASTAÑO, E.: "La cuestionable regulación penal de los delitos de financiación ilegal de partidos políticos", Revista Penal, núm. 39, 2017, pp. 125-153. 
— "El delito de financiación ilegal de partidos políticos y la Unión Europea: un caso de corrupción al margen de la normativa europea", en GONZÁLEZ CANO, M. I. (Dir.): Cooperación Judicial Penal en la Unión Europea. Reflexiones sobre algunos aspectos de la investigación y el enjuiciamiento en el espacio europeo de justicia penal", Valencia, Tirant lo Blanch, 2015, pp. 61-104.

OLAIZOLA NOGALES, I.: “«Medidas de regeneración democrática». La nueva regulación de la financiación de los partidos políticos en España”, Estudios de Deusto, vol. 63, núm. 1, 2015, pp. 327-358.

- "El delito de financiación ilegal de partidos políticos en la reforma del CP”, Diario La Ley, núm. 8516, 2015, pp. 1-6

- La financiación ilegal de los partidos políticos: un foco de corrupción, Valencia, Tirant lo Blanch, 2014.

PUENTE ABA, L. M.: El delito de financiación ilegal de partidos políticos, Valencia, Tirant lo Blanch, 2017.

QUINTERO OLIVARES, G.: “Artículo 304 bis y artículo 304 ter", en QUINTERO OLIVARES, G. (Dir.): Comentarios al Código Penal Español. Tomo II, Cizur Menor, Thomson Reuters-Aranzadi, 2016, pp. 527-537.

REBOLLO VARGAS, R.: "La polémica en el delito de financiación de partidos políticos: las puertas continúan abiertas", Estudios Penales y Criminológicos, núm. 38 (extr.), 2018, pp. 59-100.

RODRÍGUEZ-AGUILERA DE PRAT, C.: Manual de partidos políticos, Barcelona, Huygens Editorial, 2017.

RODRÍGUEZ PUERTA, M. J.: "El control externo de la actividad económico financiera de los partidos políticos en España: cuestiones a debatir", Revista General de Derecho Penal, núm. 28, 2017, pp. 1-60.

SÁINZ-CANTERO CAPARRÓS, J. E.: "Los delitos de financiación ilegal de partidos políticos", en MORILLAS CUEVAS, L. (Dir.): Sistema de Derecho Penal. Parte Especial, Madrid, Dykinson, 2016, pp.787-800. 
SANTANA VEGA, D. M.: "El delito de financiación ilegal de partidos políticos", en QUERALT JIMÉNEZ, J. y SANTANA VEGA, D. M. (Dirs.): Corrupción pública y privada en el Estado de Derecho, Valencia, Tirant lo Blanch, 2017, pp. 123-150.

SIERRA LÓPEZ, M. V.: "El delito de financiación ilegal de partidos políticos: ¿mayor eficacia en la lucha contra la corrupción?", en GÓMEZ RIVERO, M.C. y BARRERO ORTEGA, A. (Dirs.): Regeneración democrática y estrategias penales en la lucha contra la corrupción, Valencia, Tirant lo Blanch, 2017, pp. 791-825.

VERA SÁNCHEZ, J. S.: "Financiación ilegal de los partidos políticos (arts. 304 bis-304 ter)", en CORCOY BIDASOLO, M. y GÓMEZ MARTÍN, V. (Dirs.): Manual de Derecho penal, económico y de empresa. Parte general y Parte especial Tomo II, Valencia, Tirant lo Blanch, 2016, pp. 367-372. 